\title{
Changing times - a decade of empirical insight into the experience of rail passengers in Great Britain
}

\author{
Glenn Lyons ${ }^{1}$, Juliet Jain ${ }^{2}$ and Iain Weir ${ }^{3}$
}

${ }^{1}$ Corresponding Author. Centre for Transport \& Society, Faculty of Environment and Technology, University of the West of England, Frenchay Campus, Bristol, BS16 1QY, United Kingdom

Email: Glenn.Lyons@uwe.ac.uk Tel +44 1173283129 / +44 7748768404

${ }^{2}$ Centre for Transport \& Society, Faculty of Environment and Technology, University of the West of England, Frenchay Campus, Bristol, BS16 1QY, United Kingdom Email: Juliet.Jain@uwe.ac.uk

${ }^{3}$ Applied Statistics Group, Faculty of Environment and Technology, University of the West of England, Frenchay Campus, Bristol, BS16 1QY, United Kingdom

Email: Iain.Weir@uwe.ac.uk 


\begin{abstract}
In the last decade the number of rail passenger journeys in Great Britain has increased by half and car trips per person are down by a tenth. Meanwhile there has been significant growth in internet use and ownership of smartphones. Travel patterns are changing in tandem with adoption of digital age innovations. At a time when Britain is also poised to invest tens of billions of pounds in high speed rail, this paper examines how the experience of rail passengers has changed from 2004 to 2014. It draws upon questions concerning travel time use designed by its first two authors that have been included in the National Rail Passenger Survey waves conducted in Autumn 2004, 2010 and 2014, yielding over 80,000 survey responses in total.

The data reveal an ongoing decline of paper-based materials accompanying travellers in the face of increasing adoption of digital alternatives. The latter can, for many, make their journey time experience better. However, the significant increase from 2004 to 2010 in the proportion of passengers considering their time use to have been very worthwhile has not continued on to 2014. This appears to be attributable (in part) to increased crowding and reduced passenger satisfaction associated with rising demand for rail travel. The paper sets out empirical insights, drawing them together in the form of a diagrammatic depiction of the interplay of factors involved in rail passenger experience. This depiction is then used to consider the implications for the future of rail travel. While mobile technologies appear to be placing more control of passenger experience in the hands of the passengers themselves, there remain important imperatives for the rail industry to support positive use of travel time.
\end{abstract}

Keywords: travel time use; passenger rail; mobile technologies; ICTs; travel experience 


\section{$1 \quad$ Introduction}

This paper offers unique longitudinal insight into the evolving use of travel time by rail passengers in Great Britain over the period 2004 to 2014. It draws out the interplay of factors involved in rail passenger experience and considers the implications for the future of rail travel.

Historically, transport analysis has stemmed from the premise that travel is a derived demand - people are undertaking journeys at a cost to them (in terms of time and money in particular) in order to realise benefit from the activities they engage in upon reaching their destinations. Relative costs between different options for travel mode, route and destination have been important considerations in attempts to interpret and model travel behaviour. Treatment of journey experience in such contexts has tended to be in terms of journey comfort, convenience, reliability and safety, alongside time and cost. There has been little interest in accounting for how people's travel time itself is used or valued within transport analysis. This may seem rather surprising given that for England in 2014, the average person spent on average one hour per day travelling (DfT, 2014a). This amounts to a daily resource of 54 million hours for the population of England as a whole - or some 62 million hours for the population of Great Britain (England, Scotland and Wales).

However, in the last ten or so years (stemming from earlier work by Mokhtarian and Solomon (2001) which pointed to the positive utility of travel time) there has been a considerable degree of academic interest in this resource. This has been with a view to better understanding how and why people use their travel time in different ways and with what benefits to them and consequences for their behaviour (e.g. Lyons and Urry, 2005; Lyons et al., 2013). This has also led to work by the UK Department for Transport (Wardman et al., 2013; DfT, 2015) examining how people's travel time use may affect the benefits that can be attributed to schemes invested in to reduce journey times.

From 2004 to 2014 some notable developments have taken place:

Growing demand for rail travel - Since 2004, the number of rail journeys in Great Britain has increased by half (DfT, 2014b). The average number of rail trips per person per year between 2002 and 2014 has increased by 7 while the average annual number of car/van trips per person is down by 88 (DfT, 2015b: 14). The increase in rail trips involves a higher proportion of the population becoming rail users (Le Vine and Jones, 2012). This renaissance in rail may be attributed in part to the privatisation of rail and increased investment. It may 
also be a consequence of road traffic congestion. A further contributory factor may concern the rise of the digital age.

Growing presence of digital technologies in our lives - In 2004 about half of households in Great Britain had internet access. By 2014, 84\% had access (ONS, 2014). Widespread availability of fixed internet has permeated many people's personal and working lives in terms of how they communicate and consume information and services. In turn, mobile technologies have evolved rapidly. In 2010, 24\% of adults in Great Britain (aged 16+) had used the internet on their 'mobile phone' within the last 3 months. By 2014 this had increased to $58 \%$. For those aged $16-44$ the 2014 figure is much higher ( $86 \%$ in the case of $25-34$ year olds) (ONS, 2014). Our communication and consumption of information and services now accompany us increasingly when we are on the move. This seems especially true of passenger transport where, as travellers, we are not in control of the vehicle.

Growing uncertainty about the future of car travel - In a number of countries with developed economies and mature transport systems, something peculiar has happened over the ten year period - the historic growth in total car travel (total distance travelled) has not continued and car travel per person per year (measured by distance) has in some cases been in decline (Goodwin, 2012; Goodwin and Van Denker, 2013). Attention is now being devoted to better understanding the possible factors contributing to this phenomenon. These include limited road capacity in cities, a trend in urbanisation, fewer young people learning to drive and growing reliance on digital connectivity in society - as well as economic conditions. There is no professional consensus on whether the future trend in car travel will be one of growth, plateau or decline (Lyons and Goodwin, 2014). Alongside this phenomenon (which has been given the shorthand term 'peak car') there is also now much (hyped) consideration of the prospects for a future of the car as a self-driving vehicle. This sits alongside the notion of a 'sharing economy' emerging (Botsman and Rogers, 2010) in which people are more inclined to share the use of resources including vehicles. This might lead to a greater share of car use experience being as a passenger rather than as a driver.

In tandem with the developments above, questions designed by the first two authors of this paper, which seek to build a picture over time of passengers' travel time use, have been included in the National Rail Passengers Survey (NRPS) for Great Britain in 2004, 2010 and 2014. These questions offer a unique insight into framing the future of the digitally connected rail journey. 
The paper highlights how the repertoire of activities across rail passengers is changing, as mobile digital technologies become more prominent accompaniments to travel and continue to (rapidly) evolve in terms of their form and function. It also examines how worthwhile people consider their time use to be, how they plan for that time use and whether such time use is a factor in choosing to travel by train. The paper's intention is two-fold. Firstly, it provides and interprets longitudinal empirical insight into rail travel time use. Secondly, it explores what the implications might be for future developments in rail travel in a changing world.

The next section offers some further background. This is followed by an overview of the survey methodology and analysis approach. The subsequent section presents the findings from the NRPS data. Implications for the future of rail travel are considered in the concluding section.

\section{Background}

How people use their time while travelling became a topic of enquiry emerging from the idea presented by Mokhtarian and Salomon (2001) that travel time may have a positive utility. Travel time was subsequently framed as a temporal opportunity to be filled with activity, whether for work or pleasure (Lyons and Urry, 2005). A number of studies have since focused on identifying and quantifying the activities that fill travel time, the objects employed in association with time use, and the impact of such activities on a notional satisfaction with the consumption of travel time.

\subsection{International examination of rail travel time use}

Lyons et al. (2007) set a trend of enquiry by examining what rail passengers in Great Britain in 2004 did while travelling. They examined this again in 2010 (also providing a review of research into the significance, meaning and value of travel time use) (Lyons et al., 2013). Other surveys of rail passengers have used similar questions albeit in different geographic settings and with smaller sample sizes, or using observational counts to examine rail travel time use (e.g. van de Waerden et al., 2009; Russell et al., 2011; Ettema et al., 2012; Gripsrud and Hjortol, 2012; Frie et al., 2015).

In Norway, a study of rail commuters and business travellers was conducted in 2008 (Gripsrud and Hjortol, 2012). Compared to the GB 2004 survey findings from four years earlier (Lyons et al., 2007), they found a greater prevalence of mobile technologies and that more commuters and business travellers worked on the train. It was also the case that nearly 
one in four rail commuters "gets their travel time approved as working hours" (Gripsrud and Hjortol, 2012: 941).

Ettema et al. (2012) examined travel time use and satisfaction with travel amongst public transport (train, tram and bus) commuters in urban areas of Sweden in 2010. Activities undertaken most frequently concerned relaxing and entertaining, with some suggestion that this may be to alleviate boredom or stress rather than making travel a positive experience. They also suggest that (for working or studying) "[a]ctivities during travel may be undertaken not to make the trip more pleasant but to achieve satisfaction in other life domains at other times" (Ettema et al., 2012: 221).

Frie at al. (2015) considered travel satisfaction associated with on-board activities and use of information and communications technologies (ICTs) for users of Chicago Transit Authority trains in 2010. They found that "many transit riders consider transit a better use of time and/or money than driving" (Frie et al., 2015: 58). This was the case more so in relation to active time uses as opposed to passive time uses (such as listening to music). For the latter, the authors suggest that use of mobile technologies is to alleviate boredom or privatise the public space (see also Mokhtarian et al. (2015) regarding ameliorating a negative journey experience through listening to radio/music). Schwieterman et al. (2013) highlight substantial increases in mobile technology use on passenger transport in the US: up 25\% for commuter trains and 18\% in intercity trains over the period 2012-2013. Berry and Hamilton (2010) note that the noise related to mobile technology on trains may increase environmental stress (see also Bissell $(2008,2014)$ for examination of commuter stress), but argue the smart phone may also offer opportunities for people to manage being in a public space. Commuter stress is also linked to overcrowded trains and the lack of personal space (Evans and Wener, 2007).

\subsection{A complex and evolving phenomenon}

Such literature is a reminder of the many contextual factors at play relating to travel time use and of the challenges in drawing clear conclusions regarding the interplay between how time is used, the role of ICTs, passenger satisfaction and the utility of travel. International evidence spans different cultural, geographical and temporal contexts as well as different travel environments. Even as attempts to better understand the phenomenon of travel time use continue, the nature of the phenomenon is changing over time. Time use and travel behaviours are evolving in tandem with the evolution and availability of mobile technologies 
(as identified in the Introduction). Within the timeframe of the three waves of data collected for this paper, the experience of train travel is likely to have changed in a number of ways.

Firstly, mobile technology has become more ubiquitous and flexible for use in more confined spaces. As at the first quarter of $2014,44 \%$ of UK (Great Britain and Northern Ireland) households owned a tablet computer and $61 \%$ of adults owned a smart phone (Ofcom, 2014).

Secondly, the train environment in Great Britain will have been subject to some changes between 2004 and 2014. Due to the structure of the privatised industry it is difficult to track specific changes such as those to design and layout of railway carriages as they vary from route to route. However, in terms of the types of trains people are travelling on there have not been any major changes, other than the arrival of the Pendolino trains running a high speed service on the West Coast Mainline in $2009^{1}$. Of trains running in 2014, 47\% were brought in post mid-1990s privatisation, with more than half the trains remaining older former British Rail rolling stock (Brown, 2014). While some trains have been fitted with electric sockets and some offer $\mathrm{Wi}-\mathrm{Fi}$, there does not appear to be an industry-wide review of existing train interiors in relation to how passengers may want to use their time (productively or for relaxation) and how this issue affects the wider journey experience ${ }^{2}$.

Thirdly, as noted in the Introduction, there has been a continued upward trend in the numbers of people travelling by rail. This involves a continued dominance of the South East of England, not only in generating large levels of commuter traffic ( $70 \%$ of all journeys being in London and the South East), but also London acting as a central rail hub with $62 \%$ of journeys either departing from or arriving into the capital (DfT 2014b).

We now turn to consider change in rail passengers' experience more explicitly in terms of the NRPS response data covering the ten year period 2004 to 2014.

\section{$3 \quad$ Methodology}

The NRPS is administered twice a year on behalf of Transport Focus (formerly Passenger Focus until April 2015). Each survey wave obtains feedback on passenger experience and opinion for a representative sample of train journeys across Great Britain. Full details of the survey methodology are provided in BDRC Continental (2015). The full Autumn 2014

\footnotetext{
${ }^{1}$ However, major forward investment in rail within Great Britain is set out in relation to electrification, intercity fleet replacement and new high speed lines (http://www.networkrail.co.uk/improvements/).

${ }^{2}$ Meanwhile at the time of writing, the House of Commons Transport Select Committee has an open inquiry into 'Improving the Rail Passenger Experience'.
} 
questionnaire is available at http://www.transportfocus.org.uk/research/publications/ national-rail-passenger-survey-nrps-autumn-2014-questionnaire. The first two authors of this paper have designed questions concerning travel time use which Transport Focus has included in the Autumn 2004 (Lyons et al., 2007), 2010 (Lyons et al. 2013) and 2014 waves of the survey;. In 2014, respondents were asked: (i) how they spent their time on the train in question and also the activity they spent most time on; (ii) how worthwhile their time use had been; (iii) what items they had with them on the train and which they used; (iv) the extent to which they had planned in advance how to spend their time on the train; (v) whether use of their travel time had been a factor in their choice to travel by train; and (vi) to what extent ICTs had made the time spent on the train better. For (i), (ii) and (iv) the questions and response options are the same as for 2010. For (iii) 'smartphone' was added as a response option in 2014. In the case of (v), this was introduced for the first time in 2014, while (vi) is a repeat of the question asked in 2004. Changes in questions between 2004 and 2010 are explained in Lyons et al. (2013).

Response data from all three waves were assembled into a combined dataset for analysis purposes, with data screening checks undertaken in correspondence with Transport Focus. Overall sample sizes are as follows: 2004 - 25,596; 2010 - 27,556; and 2014 - 27,812. In order to ensure valid statistical testing, the response data were proportionally weighted by the train operating company, the journey purpose, and the day of travel (weekday or weekend) to be representative of the national profile of rail passengers. Analyses mainly comprised crosstabulations, with application of either pairwise z-test comparisons for significant differences in proportions, or chi-squared tests for association (with interpretation of significant associations aided by correspondence analysis). Ordinal regression was also employed. However for reasons of space, output tables are not provided. SPSS Version 22 was used for all analyses and reported statistical significance is at the 0.05 confidence level.

Certain tables of results include subscripts to denote whether or not statistically significant differences in proportions exist across categories. For example, in the first row of Table 1a when considering all purposes, proportions for sleeping/snoozing are significantly different between each survey wave in terms of decline over time (denoted by $a, b$ and c subscripts for 2004, 2010 and 2014 respectively). Meanwhile, the corresponding subscripts in the third row indicate that for working/studying there is no significant difference between the proportions in 2004 and 2010, but that these years' proportions are significantly different to that of 2014 . 
Our focus in the following section is principally on longitudinal comparison across the three waves of data, broken down by journey purpose. However, we also include selective consideration of age, gender and duration of time on the train. It should be noted that duration concerns the length of time on the specific train after receiving the questionnaire, which may not be the same as duration of the overall train journey (if involving more than one train). The dataset includes a peak/off-peak flag for the subset of respondents travelling into or out from a London terminal (for London and South East sector train operating companies). A respondent is flagged as peak period if their train journey either finished at a central London station before $10 \mathrm{am}$ or began from a central London station between $5 \mathrm{pm}$ and $7 \mathrm{pm}$ and was on a weekday.

\section{$4 \quad$ Results and analysis}

By way of context, in 2014 the overview of rail travel in the response data was as follows. $46 \%$ of journeys were commuting, $15 \%$ were for business and $40 \%$ for leisure. $46 \%$ of respondents spent less than 30 minutes on the train applicable for the survey response; $80 \%$ spent less than one hour on the train and only $6 \%$ were on the train for two or more hours. A higher proportion of commuters spent less than 30 minutes on the train concerned $(56 \%)$ compared to business travellers (34\%) and leisure travellers (45\%). Conversely, a smaller proportion of commuter respondents spent an hour or more on the train concerned $(10 \%)$ compared to business travellers (32\%) and leisure travellers $(26 \%) .45 \%$ of respondents had the destination for their train journey terminating in London. This overview is very similar to that found for 2010 and for 2004.

\subsection{How are passengers using their time?}

Respondents were asked to tick all time uses that applied to their train journey from a predefined list (see Tables 1a-d). Tables $1 \mathrm{a}$ and $1 \mathrm{~b}$ show results by journey purpose and survey wave for activities which passengers spent any time on and most time on respectively. Table 1c shows results by journey purpose, gender and age of passenger for activities which passengers spent any time on, for the 2014 survey wave. Table 1d shows results by journey purpose and duration of time on train for activities which passengers spent most time on, for the 2014 survey wave.

\section{Activities passengers spend any time on}

In terms of activities people spend any time engaged in, the following show a statistically significant decline across the three waves when considering all passengers (see Table 1a): 
sleeping/snoozing; reading for leisure; talking to other passengers; window gazing / people watching; and being bored. With the possible exception of some reading for leisure, these are all 'low-tech' activities. That they are in decline may reflect that they broadly represent what may be considered ways of passing or killing time - or that they are being substituted for by alternative 'new' ICT-enabled activities. There is only one of the pre-defined activities that shows an increase across all three waves, namely 'playing games (electronic or otherwise)'. It might have been assumed that specific ICT-dependent activities would show increases across all three waves. However, this is not the case for two reasons: (i) likely substitution effects across such activities over time (e.g. watching a film instead of listening to music); and (ii) the emergence of 'new' activities only introduced after the first wave of the survey. In the case of the latter, watching a film/video, checking emails, internet browsing and accessing social networking sites all show significant increases in engagement from 2010 to 2014. This tends to suggest that ICT-enabled activities are offering novelty or greater appeal of time use than 'low-tech' alternative activities for some passengers.

The observations above remain applicable (notwithstanding the statistical significance of some changes) for business, commute and leisure categories of travel. Across all waves: (i) a business traveller is most likely to work/study, text/phone (work), check emails and/or eat/drink during their rail journey; (ii) a commuter is most likely to sleep/snooze, read for leisure, listen to music/radio/podcast, watch a film/video, text/phone (personal), browse the internet, access social networking sites, play games and/or be bored; and (iii) a leisure traveller is most likely to talk to other passengers, window gaze/people watch and/or care for someone travelling with them. Broadly speaking, this tends to depict business travellers' rail experience as more 'industrious' (making economically productive use of their time), commuters' (who by implication encounter the rail experience more frequently, even daily) experience as more 'monotonous' and leisure travellers' experience as more 'adventurous' (soaking up and sharing their experience of the journey). However, it must be noted that how travel time is used need not be directly linked to the nature of the activity at the destination of the journey (e.g. a business traveller may read for leisure thereby treating apparent 'work' time as personal; a leisure traveller may work, treating apparent personal time as a contribution to their (paid) employment).

Across the predefined time uses considered, significant differences between men and women in 2014 in terms of activities they spend any time on during a train journey are most pronounced amongst commuters and least pronounced amongst business travellers (see Table 
1c). For commuting, men remain more likely than women to be checking emails and internet browsing, as was the case for 2010 (Lyons et al, 2013); however, the gap has closed markedly. Indeed, for business travel, there is no statistically significant difference by gender now in relation to these time uses. The following time uses are more common amongst women than men across all journey purposes in 2014: talking to other passengers; text messages/phone calls - personal; accessing social networking sites; eating/drinking; and planning onward or return journey. There are no time uses that are statistically more common amongst men than women across all journey purposes.

There are statistically significant associations for the 2014 wave between age and technologyenabled activity engagement across journey purposes (Table 1c), reflecting a decrease in engagement with increasing age. Such 'stereotypical' association between age and technology engagement is particularly pronounced for the following activities where distinct decline from those aged 34 years and under up to those aged 65 or older is observed for all journey purposes: listening to music/radio/podcast; text messages/phone calls - personal; internet browsing; and accessing social networking sites. Intriguingly, for all journey purposes, passengers aged 34 or under are more likely to be bored during a train journey than those aged 35 or above. This relationship was also found on bus travel, despite younger people being more technologically equipped (Clayton et al., forthcoming). Clayton et al. argue that young people's perception of boredom may be affected by technological expectations, thus being restricted by the travel environment may raise levels of boredom.

\section{Activities passengers spend most time on}

Passengers were also asked what activity, of those they undertook, they spent the most time on (see Table 1b). Only two activities show statistically significant change in a given direction across all three waves when considering all passengers: personal text messages/phone calls has increased over time, as has playing games (electronic or otherwise). Both remain uncommon as the activity most time is spent on. However, across the 2010 and 2014 waves, the ICT-dependent activities introduced to the survey all show significant increase as the activity most time is spent on when considering all passengers (2014 percentages shown in brackets): watching a film/video (1.3\%); checking emails (3.5\%); internet browsing $(2.7 \%)$; and accessing social networking sites $(1.4 \%)$. These are modest individually but account together for nearly a tenth of the share of activities people spend most time on - a figure which is growing. 
Across the survey waves, in terms of the activity most time is spent on: (i) business travellers are most likely to be working/studying, texting/phoning (work) and checking emails; (ii) commuters are most likely to be sleeping/snoozing, reading for leisure, listening to music/podcast/radio, watching a film/video, internet browsing, playing games and being bored; and (iii) leisure travellers are most likely to be talking to other passengers, window gazing/people watching and caring for someone travelling with them. This compares very closely in terms of association of activity to journey type with the preceding examination of how travellers spend any time on their journey.

A small number of activities account for what the majority of passengers spend most time doing. In descending order and applying across all three waves, the three most popular activities for spending most time on are as follows (with combined percentage of passengers in brackets): (i) commuters - reading for leisure, working/studying, and window gazing/people watching (2004: 74\%; 2014: 61\%); (ii) business travellers - working/studying, reading for leisure, and window gazing/people watching (2004: 77\%; 2014: 66\%); and (iii) leisure travellers - reading for leisure, window gazing/people watching, and talking to other passengers (2004: 73\%; 2014: 72\%). The erosion over time in the combined shares for these popular activities is reflective of newer technology-enabled time uses becoming more popular as main activities during train travel. For example, across journey purposes 'working or studying' shows some decline between 2010 and 2014 but meanwhile 'checking emails' shows significant increase.

Length of time on the train also affects how people overall make use of their time (see Table 1d). Window gazing/people watching is more likely as the main activity for shorter durations - especially those less than 30 minutes. Meanwhile working/studying is more common as the main activity across journey purposes for durations of one hour or longer. The survey is unable to reflect the actual distribution of time spent or share of time spent across all activities.

\section{Summary of time use}

We can say in summary about passengers' use of time that: (i) there are distinct groupings of activities that associate most with particular journey purposes; (ii) a small number of activities that are not (necessarily) ICT-dependent remain a dominant feature of rail travel time use over time; (iii) nevertheless, ICT-enabled activity is growing significantly over time and creating a richer diversity of how people are using their time overall; (iv) younger people 
are more engaged with ICTs yet more inclined to experience some boredom; (v) gender differences in time use do exist but for some time uses are reducing over time; and (vi) the richer repertoire of time use possibility may explain why the overall proportion of passengers reporting spending any of their time on the train being bored has shown significant decline over the ten year period covered by the survey waves (from $12.0 \%$ in 2004 to $8.4 \%$ in 2014).

\subsection{What artefacts do passengers have with them and use?}

Items people have with them ('to hand') during their journey afford them the possibility to undertake particular uses of their time. Whether or not they choose to make use of those items is a separate consideration and would likely depend upon their mood, energy level, travelling environment and priorities for achievement of particular personal or work goals. Table 2 summarises, by journey purpose, the use of different artefacts for rail travel across the three survey waves and also contrasts this, for 2014, with the extent to which such artefacts are to hand. The following observations can be made for 2014: (i) a substantially higher proportion of business passengers than other passengers have and use paperwork and/or a laptop computer (reflective of the purpose of their journey and the earlier observed emphasis on working/studying during their journey); (ii) a considerable proportion of all passengers have a smartphone and/or an eBook reader/tablet computer; (iii) by comparison, far fewer passengers have the 'older' new technologies (portable DVD player, MP3 player/music player, games console); and (iv) less than a quarter of passengers across journey purposes use any one given form of paper-based artefacts (newspaper, reading book, text book, magazine, paperwork).

How has the picture of mobile technologies in the travelling environment changed over the 10 year period? When considering all travellers the following three trends are observed over time:

The fall of paper-based technology - There has been a statistically significant decline from wave to wave in passengers overall having to hand and in them using the following (the latter shown in Table 2) - newspaper, text book, magazine and paperwork. This holds true across all three journey purposes with the slight exception of text book which has been declining from a low starting base. The proportion of passengers with a reading book to hand and the proportion using it during their journey did not change significantly from 2004 to 2010 but did then reduce significantly from 2010 to 2014 . This is likely to reflect in part the sharp increase in electronic devices for reading (see below). 
The rise of digital technology - Across all journey purposes, there has been a statistically significant increase from wave to wave of passengers overall having a laptop to hand and in them using it (except the increase from 2010 to 2014 in laptop use amongst commuters which is not significant). The proportion of passengers overall having an e-Book reader/tablet computer and the proportion using one have seen around a six-fold increase from 2010 to 2014. Change over time in relation to 'phones' has been complicated by the move from mobile phones to smart phones. However, it is notable that $43 \%$ of passengers reported having a smartphone with them in 2014.

The rise and fall of superseded technology - The share of all passengers having an MP3 player/music player with them increased from 2004 to 2010 but had then declined back to 2004 levels by 2014. As Table 2 shows, a similar rise and fall in use of such devices has occurred across all journey purposes. A very similar pattern is observed for games consoles. This is likely to reflect the replacement of such devices by later devices which encompass the same functionality (notably smart phones and tablet computers).

People may have an artefact with them but not use it, for at least two reasons: (i) the item is intended for potential use as part of their destination activity; or (ii) they have it with them to provide the option to use it but choose not to in practice for the given journey. This is reflected in Table 2 where, for 2014, the proportion of passengers using an item is between $36 \%$ (smartphone - business passengers) and 75\% (laptop computer - commuters) less than the proportion of passengers who report having that item with them.

\subsection{How worthwhile do people consider their time use to be?}

In terms of how people judge the use of their time on the train, we can observe the following from Table 3: (i) the significant increase from 2004 to 2010 in the proportion of passengers across all three journey purposes who considered their time use very worthwhile has not continued on to 2014 - proportions have remained more or less the same; (ii) there has been significant decline in the proportion of leisure travellers considering their time wasted across the three survey waves - meanwhile significant decline between 2004 and 2010 for business and commuting journeys has not continued on to 2014; (iii) of all three journey purposes, commuters are least likely to consider their time use very worthwhile; (iv) for the latest survey data there is almost no difference overall between men and women; (v) there is a significant age effect, with younger people more likely to consider their time wasted than older people; and (vi) time on the train during peak period rail travel is somewhat more likely 
to be considered wasted than during the off-peak period (for train journeys beginning or ending in London). The latitude for interpretation of the three different response options should be born in mind. The majority of passengers are indicating 'some use' which can itself range from quite a lot to very little and may be changing over time even though the proportion of respondents for this category may not have changed significantly.

It is important to acknowledge that passengers' views on how worthwhile their time use has been will be influenced by the travel experience itself. In all three waves, passengers were also asked to (i) rate the train they were on in terms of sufficient room for all the passengers to sit/stand (from 'very good' to 'very poor'); and (ii) indicate their satisfaction with their journey - accounting for the station from which they boarded and the train travelled on (from 'very satisfied' to 'very dissatisfied'). The results across all three waves are shown in Table 4.

For these proxy measures of experience, ordinal regression analysis confirms (both in relation to sufficient room and satisfaction) the following rank order by experience: 2010 , followed by 2014 , followed by $2004^{3}$. There has been a decline in satisfaction in conjunction with an (implied) increase in crowding from 2010 and 2014. This could explain why improvements in how worthwhile people found time use to be overall between 2004 and 2010 did not continue on to 2014. Indeed, correspondence analysis confirms a positive association in respondent data between satisfaction/seating availability and how worthwhile time use is considered to be. For train journeys beginning or ending in London, experience overall across passengers according to these proxy measures is less positive for peak period journeys than off-peak journeys.

In Q3 of 2013/14, 412.4 million franchised rail passenger journeys took place. This compares to 344.2 million in Q3 of 2010/11 and 270.9 in Q3 of 2004/05 (ORR, 2015). Hence between the 2004 and 2010 survey waves, demand had increased by $27 \%$ and between 2010 and 2014 by a further $20 \%$. It is difficult to establish how carrying capacity may have changed over the ten year period. However, the overall impression is that carrying capacity is now struggling to

\footnotetext{
${ }^{3}$ Ordinal regression analysis also reveals a rank order by experience according to journey purpose across the three waves: leisure, followed by business, followed by commute.
} 
keep pace with growing demand resulting in a dampening effect on how worthwhile people's travel time use is felt to be ${ }^{4}$.

\subsection{Does use of travel time affect the decision to travel by train?}

Table 5 reflects a new question introduced in the 2014 survey wave (hence without opportunity to consider change over time). Overall nearly three quarters of rail passengers did not consider time use an important factor in choosing to travel by train. Not being an important factor decreases with increasing amount of time spent on the train and increasing age of passenger. Travel time use is somewhat more likely to be important amongst men than women, for non-London bound journeys, and is most likely to be an important factor in choosing to travel by train for business as opposed to commuting or leisure. While the majority of rail passengers do not consider use of travel time an important factor in choosing to travel by train, correspondence analysis confirms association between the importance of time use in choice of travel mode and how worthwhile travel time use is considered to be. For passengers who considered their time use very worthwhile, $39.5 \%$ indicated travel time use as the main reason or one of the important factors for choosing to travel by train. This compares to $15.6 \%$ for passengers who considered their time was wasted. This underlines the importance of travel time use in making rail an attractive mode.

\subsection{Advance planning of time use}

Table 6 shows for 2014 the extent of advance planning for how travel time is used on the train. Ordinal regression analysis reveals a small but statistically significant increase from 2010 to 2014 in the degree of people's advance planning. The analysis also confirms, for both waves, a rank order by journey purpose of extent of advance planning: business $>$ commute $>$ leisure. Overall it appears that most commuters have established routines for their time use such that advance planning is not required. Business travellers are most inclined to prepare themselves. Leisure travellers, perhaps surprisingly, do little if any advance planning yet indicate overall that their time use is more worthwhile than for commuters. This is likely to reflect the very different expectations of the journey for different purposes and the fact that leisure travellers are more likely to be travelling with others. A positive association is revealed between advance planning and worthwhile use of travel time.

\footnotetext{
${ }^{4}$ Between 1994 and 2013 there has been a growth in passenger miles of $106 \%$ while there was only an $11 \%$ increase in total national passenger fleet size. This disparity has been accommodated through marketing and utilisation of off-peak capacity. Peak period congestion is nevertheless acknowledged as a problem on many routes which has led to the major investment programmes now in place (Brown, 2015).
} 


\subsection{The effect of electronic devices on the spending of travel time}

In 2004 and 2014, people were asked about the extent to which accompanying electronic devices had made the time spent on the train better. The results are summarised in Table 7. We can observe that: (i) from 2004 to 2014 there has been a substantial reduction in those considering the question of electronic devices and time use not applicable; (ii) in turn, from 2004 to 2014 there has been a substantial increase across rail travellers in electronic devices making the time spent on the train better; (iii) across waves, the apparent role of electronic devices in making time spent on the train better increases as the amount of time spent on the train increases, and decreases with increasing age of passengers; (iv) there is little if any difference between genders; and (v) ICTs continue to be of greater importance in supporting or addressing the 'laborious' experience of commuting and the 'industrious' experience of business travel yet have, relatively, less to offer the 'adventurous' nature of leisure travel.

\section{$5 \quad$ Implications for future rail travel}

Figure 1 offers a summary representation of what the paper's empirical findings and interpretations suggest in relation to the travel time use experience of rail passengers - at least in Great Britain.

There is a pronounced transition from paper to digital technologies taking place which is likely to continue into the future and this can increase how worthwhile travel time is. While train operators have sought to introduce Wi-Fi onto trains as well as power sockets, this transition is being brought about by consumer investment in ICTs and the transition is being progressed by successive generations of rail travellers (notably from digital immigrants to digital natives). Looking to the future, it is difficult to predict how mobile technologies will continue to evolve and how future technologies will be used by passengers to shape their individual experience and travel space. Google Glass (wearable technology in the form of a head-mounted display with voice activation) has, for the moment, been shelved but such advances could make it possible for passengers to better use their time even with a small space footprint brought about either by crowding or configurations of train carriages designed to maximise carrying capacity.

It appears that travel time use at one level is going through a revolution in terms of the items that people equip themselves with. Yet in terms of the fundamental time uses it equates more to evolution - with ICTs making it easier for the traveller to be equipped for a more flexible array of time use options. Devices such as the smartphone represent technological 
convergence where one item can perform many functions previously provided by a number of separate items (including paper-based items as well as ICTs). This is lightening the burden of being equipped for travel time use.

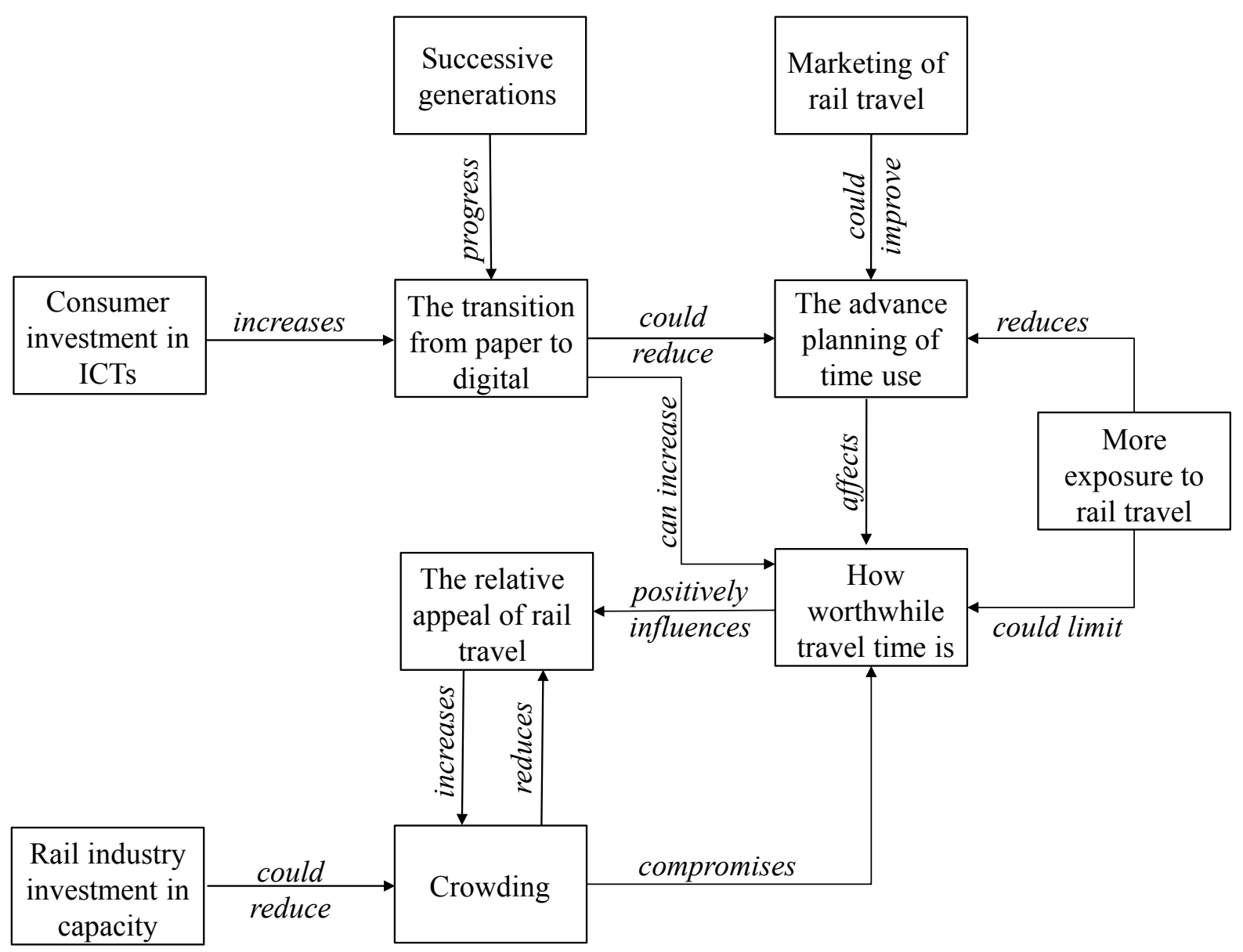

Figure 1. The interplay of factors involved in rail passenger experience

The ongoing transition to, and deeper into, digital could reduce the advance planning of time use. The rich array of functions ICTs now provide may mean that most passengers are, or will in future be, afforded flexibility in how best to use their time as their mood, needs and circumstances change during the journey, without having to undertake much advance planning of how to use their time. Nevertheless, it remains unclear the extent to which passengers are optimising their travel time use which suggests that marketing of rail travel could improve people's advance planning. This may not just be in terms of how they equip themselves with mobile technologies, but how they think through getting the most from their travel time. The variable extent of advance planning may suggest that some travellers have established routines of behaviour (associated with more exposure to rail travel) which might benefit from being 'refreshed' in order that they get more from their train journey (Watts and 
Lyons, 2010). In effect the rail industry could further promote to passengers (and prospective passengers) the opportunity to get more from the product of rail travel.

How worthwhile travel time is, positively influences the relative appeal of rail travel. Advance planning of time use can affect how worthwhile travel time is felt to be - and positively so in contrast to more exposure to rail travel (particularly for rail commuters) which could limit the positive utility of travel. Such positive utility is also compromised by crowding on trains which itself may be a product in part of positive utility of time use increasing the relative appeal of rail travel (with no signs in the immediate future that selfdriving cars will counter this appeal). Crowding itself reduces the relative appeal of rail travel.

A key question for the future is the extent to which rail industry investment in capacity could reduce crowding (depending upon the rate of demand growth driven by other factors). In Great Britain, major investment is taking place in order to address this, with 170,000 more seats at peak times every day for commuters to be delivered by 2019 (Network Rail, 2014). As noted, much of rail travel in Great Britain is associated with London and the South East. In spite of fares increasing above the rate of inflation, demand for rail travel appears rather inelastic to price. If much of the current market is captive there may be little appetite for the rail industry to invest heavily in marketing of rail travel in ways that can positively support worthwhile use of travel time. Yet travel time use may be a phenomenon that is helping to support tolerance to fare increases and bolster passenger satisfaction. It may become an even more crucial consideration for the rail industry in future (in terms of marketing of rail travel i.e. product and promotion) if either: (i) demand growth continues to outstrip capacity increase (leading to increased crowding); (ii) higher fares are needed to manage demand; or (iii) higher fares are needed to justify increased capacity.

We would advocate greater attention being given to design of railway carriages (and stations) in order provide adaptable and 'future proof' environments that can best enable future passengers, equipped with ever changing mobile technologies, to get the most from their time and hence rail travel experience. This would need to involve recognition of passengers' ability to equip themselves and craft their travel experience (and to some extent environment) and would benefit from (further) engagement with the ICT industry in terms of envisioning future scenarios). It might be something that is required as part of rolling stock refurbishment as well as for new trains and as part of new franchise agreements. Development of passenger 
environments includes addressing changing expectations of, and willingness to pay for, digital connectivity through on board Wi-Fi (provided by rail operators) and 4G (and beyond) mobile networks (provided by the telecommunications sector). Recent research has examined how passengers use and value digital connectivity (SDG, 2016). Willingness to pay for improved connectivity was found to be greatest amongst business travellers.

Alongside rail industry investment in capacity, it should continue to consider how it can assure provision of rail services that minimise the physical, cognitive and affective efforts (Stradling, 2006) of journeys for the passenger, thus enabling them to focus their attention on fruitfully consuming their travel time. This implies ensuring passengers have limited concern about navigating their journey or completing it successfully and have sufficient physical space and suitable ambiance in the train carriage to make use of their time as they wish.

In conclusion, the phenomenon of travel time use will continue to evolve and shape travel behaviour and the degree of utility (with economic value - positive or negative) associated with travel time - regardless of whether or not the rail industry or government choose to (more) actively address it. However, from the empirical insights obtained over the last ten years, we suggest that there is much to be gained by engaging with and seeking to positively exploit the phenomenon in the interests of the future of rail travel.

\section{$6 \quad$ Acknowledgements}

We are very grateful to Transport Focus for the opportunity to include questions on travel time use in the NRPS and extend our thanks in particular to David Greeno and Ian Wright for their support. Our university is acknowledged for providing the time resources to enable this research to be pursued. We thank the anonymous reviewers of the paper whose constructive feedback has helped improve the final version of the article.

\section{$7 \quad$ References}

BDRC Continental (2015). National Rail Passenger Survey Technical Guide Spring 2015.

Report to Transport Focus. http://www.transportfocus.org.uk/research/national-passengersurvey-introduction

Berry, M. and Hamilton, M. (2010). Changing urban spaces: Mobile phones on trains. Mobilities, 5(1), 111-129. 
Bissell D (2014) Encountering stressed bodies: Slow creep transformations and tipping points of commuting mobilities. Geoforum, 51, 191-201.

Bissell, D. (2008). Comfortable Bodies: Sedentary Affects. Environment and Planning A, 40(7), 1697-1712.

Botsman, R. and Rogers, R. (2010). What's Mine Is Yours. The Rise of Collaborative Consumption. How Collaborative Consumption Is Changing the Way of Life. HarperCollins UK, New York.

Brown, R. (2014). Long Term Passenger Rolling Stock Strategy for the Rail Industry. Rail industry report from Steering Group Chaired by Richard Brown, February. https://www.angeltrains.co.uk/Portals/0/News Downloads/Rolling\%20Stock\%20Strategy \%202014\%20v10.pdf

Brown, R. (2015). Long Term Passenger Rolling Stock Strategy for the Rail Industry. Third Edition. Rail industry report from Steering Group Chaired by Richard Brown, February. http://raildeliverygroup.com/files/Publications/2015-

03 long term_passenger_rolling_stock_strategy 3rd_ed.pdf

Clayton, B., Jain, J. and Parkhurst, G. (2016). An Ideal Journey: Making bus travel desirable. Forthcoming in Mobilities.

DfT (2014a). National Travel Survey: Change in Travel since 1965. Department for Transport.

DfT (2014b). Rail Trends, Great Britain 2013/14. Rail Statistics Factsheet, 15 October, Rail Executive, Department for Transport.

DfT (2015a). Understanding and Valuing Impacts of Transport Investment: Values of Travel Time Savings - Moving Britain Ahead. Department for Transport, October.

DfT (2015b). National Travel Survey: England 2014. Statistical Release, September, Department for Transport.

Ettema, D., Friman, M., Gärling, T., Olsson, L. and Fujii, S. (2012). How In-Vehicle Activities Affect Work Commuters' Satisfaction with Public Transport. Journal of Transport Geography, 24, 215-222. 
Evans, G.W. and Wener, R.E. (2007). Crowding and personal space invasion on the train: Please don't make me sit in the middle. Journal of Env. Psychology, 27(1), 90-94.

Frei, C., Mahmassani, H.S., and Frei, A. (2015) Making time count: Traveler engagement on urban transit. Transportation Research, 76(A), 58-70.

Goodwin, P. (2012). Peak travel, peak car and the future of mobility: Evidence, unresolved issues, policy implications, and a research agenda. International Transport Forum round table on "Long Run Trends in Travel Demand", Paris, OECD.

Goodwin, P. and Van Dender, K. (2013). 'Peak Car' - Themes and Issues. Transport Reviews, 33(3) - Special Issue on Peak Car, 243-254.

Gripsrud, M. and Hjorthol, R. (2012). Working on the train: from 'dead time' to productive and vital time. Transportation, 39, 941-956.

Le Vine, S. and Jones, P. (2012). On the Move: Making sense of car and train travel trends in Britain. RAC Foundation, London.

Lyons, G. and Goodwin, P. (2014). Grow, peak or plateau - the outlook for car travel. Report of a roundtable discussion in London on 20 May 2014, New Zealand Ministry of Transport, July. http://eprints.uwe.ac.uk/23277/

Lyons, G., and Urry, J. (2005). Travel Time Use in the Information Age. Transportation Research, 39 (A), 257-276.

Lyons, G., Jain, J., and Holley, D. (2007). The Use of Travel Time by Rail Passengers in Great Britain. Transportation Research, 41 (A), 107-120.

Lyons, G., Jain, J., Susilo, Y. and Atkins, S. (2013). Comparing rail passengers' travel time use in Great Britain between 2004 and 2010. Mobilities, 8(4), 560-579.

Mokhtarian, P.L., Papon, F., Goulard, M. and Diana, M. (2015). What makes travel pleasant and/or tiring? An investigation based on the French National Travel Survey. Transportation, 42(6), 1103-1128.

Mokhtarian, P.L. and Salomon, I. (2001). How derived is the demand for travel? Some conceptual and measurement considerations. Transportation Research, 35(A), 695-719. 
Network Rail (2014). Delivering a better railway for a Better Britain: our plans for 20142019. Network Rail, London.

Ofcom (2014). The Communications Market Report. Ofcom, August.

ONS (2014). Internet Access - Households and Individuals, 2014 Release. Office for National Statistics.

ORR (2015). Passenger Rail Usage 2014-15 Quarter 4 Statistical Release. Office of Rail and Road, June.

Russell, M., Price, R., Signal, L., Stanley, J., Gerring, Z. and Cumming, J. (2011). What Do Passengers Do During Travel Time? Structured Observations on Buses and Trains. Journal of Public Transportation, 14(3), 123-146.

Schwieterman, J.P., Battaglia, A., MacHarg, B. and Schulz, M. (2013). The Personal Tech Tidal Wave: The Surging Use of Electronic Devices on Intercity Buses, Planes, \& Trains 2012 - 2013: Part C: Technology in Intercity Travel Study - 2013 Update. Chaddick Institute for Metropolitan Development, DePaul University, June.

Steer Davies Gleave (2016). Mobile connectivity research study-final report. Report to the Department for Transport, London, March.

https://www.gov.uk/government/uploads/system/uploads/attachment data/file/518976/mo bile-connectivity-research-study SDG-report-with-appendices.pdf

Stradling, S. (2006). The Psychology of Travel. Review for the Foresight 'Intelligent Infrastructure Systems' Project, Office of Science and Technology, Department for Trade and Industry, London.

van der Waerden, P.J.H.J., Timmermans, H.J.P. and van Neerven, R. (2009). Extent, Nature and Covariates of Multitasking of Rail Passengers in an Urban Corridor: A Dutch Case Study. Transportation Research Record, 2110, 106-111.

Wardman, M., Batley, R., Laird, J., Mackie, P., Fowkes, A., Lyons, G., Bates, J. and Eliasson, J. (2013). Valuation of Travel Time Savings for Business Travellers. Prepared for the Department for Transport, April.

Watts, L. and Lyons, G. (2010). Travel Remedy Kit: Interventions into Train Lines and Passenger Times. In Buscher, M., Urry, J. and Witchger, K. (Eds) Mobile Methods, 189213. London: Routledge. 
Table 1a. Activities on which passengers spent any time while on the train (\% of respondents in each Autumn survey wave by journey purpose)

\begin{tabular}{|c|c|c|c|c|c|c|c|c|c|c|c|c|}
\hline \multirow[b]{2}{*}{ Time use } & \multicolumn{3}{|c|}{ All purposes } & \multicolumn{3}{|c|}{ Commute } & \multicolumn{3}{|c|}{ Business } & \multicolumn{3}{|c|}{ Leisure } \\
\hline & 2004 & 2010 & 2014 & 2004 & 2010 & 2014 & 2004 & 2010 & 2014 & 2004 & 2010 & 2014 \\
\hline Sleeping/snoozing & $14.6_{\mathrm{a}}$ & $13.0_{\mathrm{b}}$ & $10.1_{\mathrm{c}}$ & $18.1_{\mathrm{a}}$ & $16.2_{\mathrm{b}}$ & $11.7_{\mathrm{c}}$ & $13.4_{\mathrm{a}}$ & $11.9 \mathrm{a}$ & $9.7_{\mathrm{b}}$ & $11.3_{\mathrm{a}}$ & $9.6_{\mathrm{b}}$ & $8.5_{\mathrm{c}}$ \\
\hline Reading for leisure & $53.7 \mathrm{a}$ & $50.2_{\mathrm{b}}$ & $40.5_{\mathrm{c}}$ & $61.4_{\mathrm{a}}$ & $58.3_{\mathrm{b}}$ & $45.4_{c}$ & $46.6_{\mathrm{a}}$ & $39.9_{\mathrm{b}}$ & $32.0_{\mathrm{c}}$ & $47.9 \mathrm{a}$ & $44.7_{\mathrm{b}}$ & $38.0_{\mathrm{c}}$ \\
\hline Working/studying (reading/writing/thinking) & $25.5 \mathrm{a}$ & $25.3_{\mathrm{a}}$ & $21.2_{\mathrm{b}}$ & $27.5_{\mathrm{a}}$ & $29.7_{b}$ & $23.9_{\mathrm{c}}$ & $51.5_{\mathrm{a}}$ & $48.6_{b}$ & $45.2_{\mathrm{c}}$ & $12.9 \mathrm{a}$ & $10.8_{\mathrm{b}}$ & $8.9_{\mathrm{c}}$ \\
\hline Talking to other passengers & $15.5_{\mathrm{a}}$ & $13.1_{b}$ & $11.6_{\mathrm{c}}$ & $10.8_{\mathrm{a}}$ & $9.6_{\mathrm{b}}$ & $6.5_{\mathrm{c}}$ & $12.6_{a}$ & $10.3_{\mathrm{b}}$ & $9.4_{b}$ & $21.7 \mathrm{a}$ & $18.3_{\mathrm{b}}$ & $18.2_{\mathrm{b}}$ \\
\hline Window gazing/people watching & $57.1_{\mathrm{a}}$ & $49.2 \mathrm{~b}$ & $43.7_{\mathrm{c}}$ & $49.0_{\mathrm{a}}$ & $43.4_{b}$ & $37.2_{\mathrm{c}}$ & $53.5_{\mathrm{a}}$ & $42.4_{b}$ & $40.3_{\mathrm{b}}$ & $67.4 \mathrm{a}$ & $58.8_{\mathrm{b}}$ & $52.5_{\mathrm{c}}$ \\
\hline Listening to music/radio/podcast & $9.0_{\mathrm{a}}$ & $19.0_{b}$ & $14.6_{\mathrm{c}}$ & $12.4_{\mathrm{a}}$ & $26.7_{b}$ & $20.2_{\mathrm{c}}$ & $4.5_{\mathrm{a}}$ & $12.4_{b}$ & $10.6_{\mathrm{c}}$ & $6.9 \mathrm{a}$ & $12.3_{\mathrm{b}}$ & $9.5_{\mathrm{c}}$ \\
\hline Watching a film/video & N/A & $1.6_{\mathrm{a}}$ & $2.6_{b}$ & N/A & $2.4_{a}$ & $3.7_{b}$ & $\mathrm{~N} / \mathrm{A}$ & $1.1_{\mathrm{a}}$ & $2.7_{\mathrm{b}}$ & N/A & $0.9 \mathrm{a}$ & $1.2_{\mathrm{b}}$ \\
\hline Text messages/phone calls - work & $8.2 \mathrm{a}$ & $14.4_{b}$ & $12.8_{\mathrm{c}}$ & $8.1_{\mathrm{a}}$ & $17.0_{\mathrm{b}}$ & $15.0_{\mathrm{c}}$ & $22.1_{\mathrm{a}}$ & $30.1_{b}$ & $30.1_{b}$ & $2.8_{\mathrm{a}}$ & $5.0_{\mathrm{b}}$ & $3.5_{\mathrm{c}}$ \\
\hline Text messages/phone calls - personal & $18.7 \mathrm{a}$ & $28.6_{b}$ & $27.6_{\mathrm{c}}$ & $20.2_{\mathrm{a}}$ & $32.9_{\mathrm{b}}$ & $30.5_{\mathrm{c}}$ & $15.1_{\mathrm{a}}$ & $24.2 \mathrm{~b}$ & $24.8_{\mathrm{b}}$ & $18.4 \mathrm{a}$ & $25.3_{\mathrm{b}}$ & $25.4_{b}$ \\
\hline Checking emails & N/A & $16.1_{\mathrm{a}}$ & $25.1_{\mathrm{b}}$ & N/A & $19.8_{\mathrm{a}}$ & $30.4_{b}$ & $\mathrm{~N} / \mathrm{A}$ & $29.3 \mathrm{a}$ & $41.4_{b}$ & N/A & $6.4_{a}$ & $12.8_{\mathrm{b}}$ \\
\hline Internet browsing & N/A & $9.3_{\mathrm{a}}$ & $18.0_{\mathrm{b}}$ & N/A & $12.5_{\mathrm{a}}$ & $23.1_{\mathrm{b}}$ & N/A & $10.1_{\mathrm{a}}$ & $17.0_{\mathrm{b}}$ & $\mathrm{N} / \mathrm{A}$ & $5.3_{\mathrm{a}}$ & $12.5_{\mathrm{b}}$ \\
\hline Accessing social networking sites & $\mathrm{N} / \mathrm{A}$ & $5.8_{\mathrm{a}}$ & $12.2_{\mathrm{b}}$ & N/A & $7.6_{\mathrm{a}}$ & $15.5_{\mathrm{b}}$ & $\mathrm{N} / \mathrm{A}$ & $4.7 \mathrm{a}$ & $9.7_{\mathrm{b}}$ & $\mathrm{N} / \mathrm{A}$ & $4.1_{\mathrm{a}}$ & $9.3_{\mathrm{b}}$ \\
\hline Eating/drinking & $14.9_{\mathrm{a}}$ & $15.8_{\mathrm{b}}$ & $13.0_{\mathrm{c}}$ & $8.6_{\mathrm{a}}$ & $11.8_{\mathrm{b}}$ & $9.4_{a}$ & $21.3 \mathrm{a}$ & $20.1_{\mathrm{a}, \mathrm{b}}$ & $18.9_{\mathrm{b}}$ & $19.4_{\mathrm{a}}$ & $19.0_{\mathrm{a}}$ & $15.0_{\mathrm{b}}$ \\
\hline Caring for someone travelling with you (including children) & $2.2_{\mathrm{a}}$ & $2.3_{\mathrm{a}}$ & $2.1_{\mathrm{a}}$ & $0.3_{\mathrm{a}}$ & $0.7_{\mathrm{b}}$ & $0.8_{\mathrm{b}}$ & $0.4_{a}$ & $0.4_{a}$ & $0.2_{\mathrm{a}}$ & $5.1_{\mathrm{a}}$ & $4.9_{\mathrm{a}, \mathrm{b}}$ & $4.2 \mathrm{~b}$ \\
\hline Playing games (electronic or otherwise) & $1.6_{\mathrm{a}}$ & $3.9_{\mathrm{b}}$ & $4.5_{\mathrm{c}}$ & $1.9 \mathrm{a}$ & $5.1_{\mathrm{b}}$ & $5.5_{\mathrm{b}}$ & $1.0_{\mathrm{a}}$ & $2.5_{\mathrm{b}}$ & $3.1_{\mathrm{b}}$ & $1.6_{\mathrm{a}}$ & $3.0_{\mathrm{b}}$ & $3.8_{\mathrm{c}}$ \\
\hline Being bored & $12.0_{\mathrm{a}}$ & $9.8_{\mathrm{b}}$ & $8.4_{c}$ & $14.3_{\mathrm{a}}$ & $12.1_{\mathrm{b}}$ & $9.5_{\mathrm{c}}$ & $9.3_{\mathrm{a}}$ & $7.7_{\mathrm{b}}$ & $6.5_{\mathrm{b}}$ & $10.5_{\mathrm{a}}$ & $8.0_{\mathrm{b}}$ & $7.8_{\mathrm{b}}$ \\
\hline Being anxious about the journey (e.g. delays or where to get off) & $6.4_{a}$ & $12.6_{\mathrm{b}}$ & $14.2_{\mathrm{c}}$ & $7 . \mathrm{a}_{\mathrm{a}}$ & $11.9_{\mathrm{b}}$ & $14.4_{\mathrm{c}}$ & $4.9 \mathrm{a}$ & $13.8_{\mathrm{b}}$ & $12.7_{\mathrm{b}}$ & $6.1_{\mathrm{a}}$ & $12.9_{\mathrm{b}}$ & $14.6_{c}$ \\
\hline Planning onward or return journey & $7.3_{\mathrm{a}}$ & $5.8_{\mathrm{b}}$ & $5.8_{\mathrm{b}}$ & $4.5_{\mathrm{a}}$ & $4.4_{\mathrm{a}}$ & $4.5_{\mathrm{a}}$ & $9.3_{\mathrm{a}}$ & $7.1_{\mathrm{b}}$ & $7.2 \mathrm{~b}$ & $9.5_{\mathrm{a}}$ & $7.0_{\mathrm{b}}$ & $6.9_{\mathrm{b}}$ \\
\hline Other & $11.7_{\mathrm{a}}$ & $8.1_{b}$ & $0.0_{\mathrm{c}}$ & $10.1_{\mathrm{a}}$ & $6.8_{\mathrm{b}}$ & $0.0_{\mathrm{c}}$ & $13.4_{\mathrm{a}}$ & $10.0_{\mathrm{b}}$ & $0.0_{\mathrm{c}}$ & $12.8_{\mathrm{a}}$ & $8.9_{\mathrm{b}}$ & $0.0_{\mathrm{c}}$ \\
\hline Sample size & 25,596 & 27,556 & 27,812 & 11,327 & 12,728 & 12,644 & 4,055 & 4,243 & 4,191 & 10,215 & 10,584 & 10,978 \\
\hline
\end{tabular}

N/A - not available as a response category in the survey wave

Each subscript letter denotes, per journey purpose, a subset of survey wave categories whose column proportions to do differ significantly from each other at the 0.05 level 
Table 1b. Activities on which passengers spent most time while on the train (\% of respondents in each Autumn survey wave by journey purpose)

\begin{tabular}{|c|c|c|c|c|c|c|c|c|c|c|c|c|}
\hline \multirow[b]{2}{*}{ Time use } & \multicolumn{3}{|c|}{ All purposes } & \multicolumn{3}{|c|}{ Commute } & \multicolumn{3}{|c|}{ Business } & \multicolumn{3}{|c|}{ Leisure } \\
\hline & 2004 & 2010 & 2014 & 2004 & 2010 & 2014 & 2004 & 2010 & 2014 & 2004 & 2010 & 2014 \\
\hline Sleeping/snoozing & $3.7_{\mathrm{a}}$ & $3.5_{\mathrm{a}}$ & $2.8_{\mathrm{b}}$ & $5.2 \mathrm{a}$ & $4.3_{\mathrm{b}}$ & $3.4_{\mathrm{c}}$ & $3.0_{\mathrm{a}}$ & $2.9_{\mathrm{a}}$ & $2.7 \mathrm{a}$ & $2.4_{\mathrm{a}, \mathrm{b}}$ & $2.8_{\mathrm{b}}$ & $2.1_{\mathrm{a}}$ \\
\hline Reading for leisure & $37.9 \mathrm{a}$ & $37.0_{\mathrm{a}}$ & $32.6_{b}$ & $46.5 \mathrm{a}$ & $43.4_{b}$ & $37.2_{\mathrm{c}}$ & $27.3_{\mathrm{a}}$ & $26.0_{\mathrm{a}}$ & $22.6_{b}$ & $32.4_{\mathrm{a}, \mathrm{b}}$ & $33.2_{\mathrm{b}}$ & $31.0_{\mathrm{a}}$ \\
\hline Working/studying (reading/writing/thinking) & $14.5_{\mathrm{a}}$ & $13.7_{\mathrm{a}}$ & $12.4_{b}$ & $14.5 \mathrm{a}$ & $13.6_{\mathrm{a}, \mathrm{b}}$ & $12.7_{\mathrm{b}}$ & $34.7 \mathrm{a}$ & $33.4_{\mathrm{a}, \mathrm{b}}$ & $30.7_{b}$ & $6.4_{\mathrm{a}}$ & $5.6_{a, b}$ & $5.2_{\mathrm{b}}$ \\
\hline Talking to other passengers & $6.7 \mathrm{a}$ & $5.2_{\mathrm{b}}$ & $6.8_{\mathrm{a}}$ & $4.5_{\mathrm{a}}$ & $2.8_{\mathrm{b}}$ & $3.3_{\mathrm{b}}$ & $5.5_{\mathrm{a}}$ & $4.8_{\mathrm{a}}$ & $4.8_{\mathrm{a}}$ & $9.7 \mathrm{a}$ & $8.4_{b}$ & $11.5_{\mathrm{c}}$ \\
\hline Window gazing/people watching & $20.4_{a}$ & $19.0_{\mathrm{b}}$ & $18.6_{b}$ & $13.0_{\mathrm{a}}$ & $12.1_{\mathrm{a}, \mathrm{b}}$ & $11.3_{\mathrm{b}}$ & $14.5_{\mathrm{a}}$ & $12.1_{\mathrm{b}}$ & $12.5_{\mathrm{a}, \mathrm{b}}$ & $31.1_{\mathrm{a}}$ & $31.0_{\mathrm{a}, \mathrm{b}}$ & $29.3_{\mathrm{b}}$ \\
\hline Listening to music/radio/podcast & $3.7 \mathrm{a}$ & $8.6_{b}$ & $6.8_{\mathrm{c}}$ & $5.0_{\mathrm{a}}$ & $11.1_{\mathrm{b}}$ & $9.4_{c}$ & $1.2 \mathrm{a}$ & $5.9_{\mathrm{b}}$ & $4.3_{\mathrm{c}}$ & $3.1_{\mathrm{a}}$ & $6.5_{\mathrm{b}}$ & $4.7_{\mathrm{c}}$ \\
\hline Watching a film/video & N/A & $0.5_{\mathrm{b}}$ & $1.3_{\mathrm{c}}$ & $\mathrm{N} / \mathrm{A}$ & $0.7_{\mathrm{b}}$ & $1.9_{\mathrm{c}}$ & $\mathrm{N} / \mathrm{A}$ & $0.5_{\mathrm{b}}$ & $1.8_{\mathrm{c}}$ & $\mathrm{N} / \mathrm{A}$ & $0.2_{\mathrm{b}}$ & $0.6_{\mathrm{c}}$ \\
\hline Text messages/phone calls - work & $0.6_{a}$ & $1.2_{\mathrm{b}}$ & $1.2_{\mathrm{b}}$ & $0.5_{\mathrm{a}}$ & $1.3_{\mathrm{b}}$ & $1.2 \mathrm{~b}$ & $1.8_{\mathrm{a}}$ & $3.0_{\mathrm{b}}$ & $3.6_{\mathrm{b}}$ & $0.2_{\mathrm{a}}$ & $0.4_{a}$ & $0.3_{\mathrm{a}}$ \\
\hline Text messages/phone calls - personal & $1.0_{\mathrm{a}}$ & $2.0_{\mathrm{b}}$ & $2.8_{\mathrm{c}}$ & $0.9_{\mathrm{a}}$ & $2.3_{\mathrm{b}}$ & $2.9_{\mathrm{c}}$ & $1.0_{\mathrm{a}}$ & $1.1_{\mathrm{a}}$ & $1.7 \mathrm{a}$ & $1.2_{\mathrm{a}}$ & $2.2 \mathrm{~b}$ & $3.1_{\mathrm{c}}$ \\
\hline Checking emails & N/A & $2.2_{\mathrm{b}}$ & $3.5_{\mathrm{c}}$ & N/A & $2.5_{\mathrm{b}}$ & $4.3_{\mathrm{c}}$ & N/A & $4.9_{\mathrm{b}}$ & $7.7_{\mathrm{c}}$ & $\mathrm{N} / \mathrm{A}$ & $0.6_{\mathrm{b}}$ & $1.1_{\mathrm{c}}$ \\
\hline Internet browsing & N/A & $0.8_{\mathrm{b}}$ & $2.7_{\mathrm{c}}$ & N/A & $1.1_{\mathrm{b}}$ & $3.8_{\mathrm{c}}$ & N/A & $0.6_{\mathrm{b}}$ & $1.9 \mathrm{c}$ & $\mathrm{N} / \mathrm{A}$ & $0.6_{\mathrm{b}}$ & $1.9_{\mathrm{c}}$ \\
\hline Accessing social networking sites & N/A & $0.5_{\mathrm{b}}$ & $1.4_{\mathrm{c}}$ & $\mathrm{N} / \mathrm{A}$ & $0.5_{\mathrm{b}}$ & $1.8_{\mathrm{c}}$ & $\mathrm{N} / \mathrm{A}$ & $0.6_{\mathrm{b}}$ & $0.7_{\mathrm{b}}$ & $\mathrm{N} / \mathrm{A}$ & $0.3_{\mathrm{b}}$ & $1.3_{\mathrm{c}}$ \\
\hline Eating/drinking & $0.3_{\mathrm{a}}$ & $0.5 \mathrm{~b}$ & $0.6_{\mathrm{b}}$ & $0 . \mathrm{a}_{\mathrm{a}}$ & $0.2_{\mathrm{a}}$ & $0.4_{\mathrm{b}}$ & $0.6_{\mathrm{a}}$ & $0.5_{\mathrm{a}}$ & $0.9 \mathrm{a}$ & $0.4_{\mathrm{a}}$ & $0.8_{\mathrm{b}}$ & $0.6_{\mathrm{a}, \mathrm{b}}$ \\
\hline Caring for someone travelling with you (including children) & $1.3_{\mathrm{a}}$ & $1.3_{\mathrm{a}}$ & $1.3_{\mathrm{a}}$ & $0.1_{\mathrm{a}}$ & $0.2 \mathrm{a}$ & $0.6_{\mathrm{b}}$ & $0.2 \mathrm{a}$ & $0.3_{\mathrm{a}}$ & $0.0_{\mathrm{a}}$ & $3.0_{\mathrm{a}}$ & $3.2 \mathrm{a}$ & $2.7_{\mathrm{a}}$ \\
\hline Playing games (electronic or otherwise) & $0.3_{\mathrm{a}}$ & $0.9_{\mathrm{b}}$ & $1.5_{\mathrm{c}}$ & $0.4_{\mathrm{a}}$ & $1.1_{\mathrm{b}}$ & $2.0_{\mathrm{c}}$ & $0.2_{\mathrm{a}}$ & $0.7_{\mathrm{b}}$ & $1.0_{\mathrm{b}}$ & $0.3_{\mathrm{a}}$ & $0.6_{\mathrm{b}}$ & $1.2_{\mathrm{c}}$ \\
\hline Being bored & $1.9_{\mathrm{a}, \mathrm{b}}$ & $1.6_{\mathrm{b}}$ & $2.1_{\mathrm{a}}$ & $2.5_{\mathrm{a}}$ & $1.8_{\mathrm{b}}$ & $2.3_{\mathrm{a}}$ & $1.1_{\mathrm{a}}$ & $1.0_{\mathrm{a}}$ & $1.4_{\mathrm{a}}$ & $1.6_{\mathrm{a}}$ & $1.7_{\mathrm{a}, \mathrm{b}}$ & $2.1_{\mathrm{b}}$ \\
\hline Being anxious about the journey (e.g. delays or where to get off) & $0.7 \mathrm{a}$ & $0.8_{\mathrm{a}}$ & $0.9 \mathrm{a}$ & $0.8_{\mathrm{a}, \mathrm{b}}$ & $0.6_{\mathrm{b}}$ & $1.1_{\mathrm{a}}$ & $0.5_{\mathrm{a}}$ & $0.9 \mathrm{a}$ & $0.6_{\mathrm{a}}$ & $0.7 \mathrm{a}$ & $0.9 \mathrm{a}$ & $0.7_{\mathrm{a}}$ \\
\hline Planning onward or return journey & $0.4_{\mathrm{a}}$ & $0.6_{\mathrm{b}}$ & $0.6_{\mathrm{b}}$ & $0.2_{\mathrm{a}}$ & $0.4_{a}$ & $0.4_{a}$ & $0.5_{\mathrm{a}}$ & $0.7 \mathrm{a}$ & $1.0_{\mathrm{a}}$ & $0.5_{\mathrm{a}}$ & $0.9_{\mathrm{b}}$ & $0.8_{\mathrm{a}, \mathrm{b}}$ \\
\hline Other & $6.6_{a}$ & $0.0_{\mathrm{b}}$ & $0.0_{\mathrm{b}}$ & $5.7 \mathrm{a}$ & $0.0_{\mathrm{b}}$ & $0.0_{\mathrm{b}}$ & $7.9_{\mathrm{a}}$ & $0.0_{\mathrm{b}}$ & $0.0_{\mathrm{b}}$ & $7.1_{\mathrm{a}}$ & $0.0_{b}$ & $0.1_{b}$ \\
\hline Sample size & 22,740 & 17,272 & 19,091 & 10,144 & 8,279 & 8,725 & 3,649 & 2,668 & 2,806 & 8,949 & 6,325 & 7,562 \\
\hline
\end{tabular}

N/A - not available as a response category in the survey wave

Each subscript letter denotes, per journey purpose, a subset of survey wave categories whose column proportions to do differ significantly from each other at the 0.05 level 
Table 1c. Activities on which passengers spent any time while on the train (2014 Autumn survey wave - \% of respondents in each category by journey purpose)

\begin{tabular}{|c|c|c|c|c|c|c|c|c|c|c|c|c|c|c|c|}
\hline \multirow[b]{3}{*}{ Time use } & \multicolumn{5}{|c|}{ Commute } & \multicolumn{5}{|c|}{ Business } & \multicolumn{5}{|c|}{ Leisure } \\
\hline & \multicolumn{2}{|c|}{ Gender } & \multicolumn{3}{|c|}{ Age (years) } & \multicolumn{2}{|c|}{ Gender } & \multicolumn{3}{|c|}{ Age (years) } & \multicolumn{2}{|c|}{ Gender } & \multicolumn{3}{|c|}{ Age (years) } \\
\hline & Male & $\overline{\text { Female }}$ & $\leq 34$ & $35-64$ & $\geq 65$ & Male & $\overline{\text { Female }}$ & $\leq 34$ & $35-64$ & $\geq 65$ & Male & $\overline{\text { Female }}$ & $\leq 34$ & $35-64$ & $\geq 65$ \\
\hline Sleeping/snoozing & $13.9_{\mathrm{a}}$ & $10.1_{\mathrm{b}}$ & $12.7_{\mathrm{a}}$ & $9.4_{b}$ & $7.1_{b}$ & $9.3_{\mathrm{a}}$ & $10.2_{\mathrm{a}}$ & $11.3_{\mathrm{a}}$ & $8.2_{\mathrm{b}}$ & $7.3_{\mathrm{b}}$ & $9.3_{\mathrm{a}}$ & $7.9 \mathrm{~b}$ & $11.7 \mathrm{a}$ & $10.2_{\mathrm{b}}$ & $7.8_{\mathrm{c}}$ \\
\hline Reading for leisure & $46.1_{\mathrm{a}}$ & $45.3_{\mathrm{a}}$ & $38.1_{\mathrm{a}}$ & $49.3_{\mathrm{b}}$ & $52.0_{\mathrm{b}}$ & $32.7 \mathrm{a}$ & $32.3_{\mathrm{a}}$ & $27.8_{\mathrm{a}}$ & $32.3_{\mathrm{b}}$ & $42.1_{c}$ & $38.1_{\mathrm{a}}$ & $38.2_{\mathrm{a}}$ & $27.1_{\mathrm{a}}$ & $38.0_{\mathrm{b}}$ & $45.5_{\mathrm{c}}$ \\
\hline Working/studying (reading/writing/thinking) & $26.3_{\mathrm{a}}$ & $21.8_{\mathrm{b}}$ & $23.4_{a}$ & $24.1_{\mathrm{a}}$ & $23.1_{\mathrm{a}}$ & $47.1_{\mathrm{a}}$ & $43.9_{\mathrm{b}}$ & $14.2_{\mathrm{a}}$ & $9.8_{\mathrm{b}}$ & $4.6_{\mathrm{c}}$ & $9.0_{\mathrm{a}}$ & $9.2_{\mathrm{a}}$ & $22.0_{\mathrm{a}}$ & $23.8_{\mathrm{b}}$ & $9.5 \mathrm{c}$ \\
\hline Talking to other passengers & $5.8_{\mathrm{a}}$ & $7.0_{\mathrm{b}}$ & $7.9 \mathrm{a}$ & $5.8_{\mathrm{b}}$ & $4.8_{\mathrm{b}}$ & $7.6_{\mathrm{a}}$ & $12.2_{\mathrm{b}}$ & $11.3_{\mathrm{a}}$ & $9.5_{\mathrm{a}}$ & $7.7 \mathrm{a}$ & $15.2_{\mathrm{a}}$ & $20.4_{b}$ & $20.4_{a}$ & $18.4_{b}$ & $17.3_{\mathrm{b}}$ \\
\hline Window gazing/people watching & $34.8_{\mathrm{a}}$ & $39.7_{\mathrm{b}}$ & $47.2_{\mathrm{a}}$ & $32.7_{\mathrm{b}}$ & $34.8_{\mathrm{b}}$ & $40.1_{\mathrm{a}}$ & $42.0_{\mathrm{a}}$ & $45.6_{\mathrm{a}}$ & $39.8_{\mathrm{b}}$ & $42.0_{\mathrm{a}, \mathrm{b}}$ & $51.0_{\mathrm{a}}$ & $54.3_{\mathrm{b}}$ & $53.8_{\mathrm{a}, \mathrm{b}}$ & $51.4_{\mathrm{b}}$ & $54.7 \mathrm{a}$ \\
\hline Listening to music/radio/podcast & $21.2_{\mathrm{a}}$ & $19.5_{b}$ & $34.4_{\mathrm{a}}$ & $14.1_{\mathrm{b}}$ & $4.0_{\mathrm{c}}$ & $10.9_{\mathrm{a}}$ & $10.4_{\mathrm{a}}$ & $19.8_{\mathrm{a}}$ & $9.4_{b}$ & $5.6_{\mathrm{c}}$ & $10.8_{\mathrm{a}}$ & $9.0_{\mathrm{b}}$ & $28.9 \mathrm{a}$ & $7.2_{\mathrm{b}}$ & $1.5 \mathrm{c}$ \\
\hline Watching a film/video & $4.6_{\mathrm{a}}$ & $3.1_{\mathrm{b}}$ & $4.7 \mathrm{a}$ & $3.5_{\mathrm{b}}$ & $0.3_{\mathrm{c}}$ & $3.4_{a}$ & $2.0_{\mathrm{b}}$ & $5.7_{\mathrm{a}}$ & $2.2_{\mathrm{b}}$ & $1.8_{\mathrm{b}}$ & $1.2 \mathrm{a}$ & $1.3_{\mathrm{a}}$ & $3.9 \mathrm{a}$ & $1.0_{\mathrm{b}}$ & $0.1_{\mathrm{c}}$ \\
\hline Text messages/phone calls - work & $15.5_{\mathrm{a}}$ & $14.6_{\mathrm{a}}$ & $15.0_{\mathrm{a}}$ & $15.2_{\mathrm{a}}$ & $9.3_{\mathrm{b}}$ & $30.0_{\mathrm{a}}$ & $31.3_{\mathrm{a}}$ & $34.6_{a}$ & $31.2_{\mathrm{a}}$ & $16.6_{b}$ & $3.8_{\mathrm{a}}$ & $3.3_{\mathrm{a}}$ & $5.6_{a}$ & $4.2 \mathrm{~b}$ & $1.0_{\mathrm{c}}$ \\
\hline Text messages/phone calls - personal & $23.8_{\mathrm{a}}$ & $36.5_{b}$ & $44.1_{\mathrm{a}}$ & $24.7_{b}$ & $13.5_{\mathrm{c}}$ & $21.1_{\mathrm{a}}$ & $31.2_{\mathrm{b}}$ & $37.2_{\mathrm{a}}$ & $23.8_{\mathrm{b}}$ & $13.4_{\mathrm{c}}$ & $18.4_{\mathrm{a}}$ & $30.3_{\mathrm{b}}$ & $46.3 \mathrm{a}$ & $26.5_{b}$ & $11.5_{\mathrm{c}}$ \\
\hline Checking emails & $32.1_{a}$ & $29.3_{b}$ & $33.4_{a}$ & $29.6_{b}$ & $18.5_{\mathrm{c}}$ & $43.5_{\mathrm{a}}$ & $40.5_{\mathrm{a}}$ & $44.3_{\mathrm{a}}$ & $43.2_{\mathrm{a}}$ & $27.3_{b}$ & $43.5_{\mathrm{a}}$ & $40.5_{\mathrm{a}}$ & $21.6_{a}$ & $14.8_{\mathrm{b}}$ & $3.8_{\mathrm{c}}$ \\
\hline Internet browsing & $24.4_{\mathrm{a}}$ & $22.1_{\mathrm{b}}$ & $36.1_{a}$ & $17.5_{\mathrm{b}}$ & $3.8_{\mathrm{c}}$ & $17.0_{\mathrm{a}}$ & $17.8_{\mathrm{a}}$ & $35.2 \mathrm{a}$ & $14.2_{\mathrm{b}}$ & $8.9_{\mathrm{c}}$ & $13.8_{\mathrm{a}}$ & $12.0_{\mathrm{b}}$ & $33.8 \mathrm{a}$ & $11.2_{\mathrm{b}}$ & $1.8_{\mathrm{c}}$ \\
\hline Accessing social networking sites & $12.9 \mathrm{a}$ & $18.2_{\mathrm{b}}$ & $29.8_{\mathrm{a}}$ & $9.3_{\mathrm{b}}$ & $1.0_{\mathrm{c}}$ & $8.7_{\mathrm{a}}$ & $11.5_{\mathrm{b}}$ & $25.0_{\mathrm{a}}$ & $7.5_{b}$ & $1.5_{\mathrm{c}}$ & $7.8_{a}$ & $10.3_{\mathrm{b}}$ & $29.9 \mathrm{a}$ & $6.8_{\mathrm{b}}$ & $0.8_{\mathrm{c}}$ \\
\hline Eating/drinking & $8.2_{\mathrm{a}}$ & $10.5_{\mathrm{b}}$ & $14.3_{\mathrm{a}}$ & $7.0_{\mathrm{b}}$ & $10.3_{\mathrm{c}}$ & $15.9 \mathrm{a}$ & $23.5_{\mathrm{b}}$ & $24.9 \mathrm{a}$ & $18.5_{\mathrm{b}}$ & $12.5_{\mathrm{c}}$ & $12.6_{\mathrm{a}}$ & $16.5_{\mathrm{b}}$ & $19.9 \mathrm{a}$ & $15.6_{\mathrm{b}}$ & $11.3_{\mathrm{c}}$ \\
\hline Caring for someone travelling with you (including children) & $0.4_{\mathrm{a}}$ & $1.1_{\mathrm{b}}$ & $0.5_{\mathrm{a}}$ & $0.9 \mathrm{a}$ & $1.3_{\mathrm{a}}$ & $0.1_{\mathrm{a}}$ & $0.3_{\mathrm{a}}$ & $0.3_{\mathrm{a}}$ & $0.2_{\mathrm{a}}$ & $0.0_{\mathrm{a}}$ & $2.4_{\mathrm{a}}$ & $5.3_{\mathrm{b}}$ & $4.6_{\mathrm{a}}$ & $5.0_{\mathrm{a}}$ & $2.8 \mathrm{~b}$ \\
\hline Playing games (electronic or otherwise) & $6.4_{a}$ & $4.9_{\mathrm{b}}$ & $6.9_{\mathrm{a}}$ & $5.0_{\mathrm{b}}$ & $4.0_{\mathrm{b}}$ & $2.9_{\mathrm{a}}$ & $3.6_{a}$ & $5.1_{\mathrm{a}}$ & $2.8_{\mathrm{b}}$ & $2.1_{b}$ & $3.3_{\mathrm{a}}$ & $4.2_{\mathrm{b}}$ & $5.7 \mathrm{a}$ & $4.3_{\mathrm{b}}$ & $1.9 \mathrm{c}$ \\
\hline Being bored & $10.1_{\mathrm{a}}$ & $9.1_{\mathrm{a}}$ & $17.9 \mathrm{a}$ & $5.5_{\mathrm{b}}$ & $5.8_{\mathrm{b}}$ & $7.4_{a}$ & $5.6 \mathrm{~b}$ & $12.4_{\mathrm{a}}$ & $5.5_{\mathrm{b}}$ & $4.7_{b}$ & $9.2 \mathrm{a}$ & $7.1_{\mathrm{b}}$ & $12.4_{a}$ & $5.5_{\mathrm{b}}$ & $4.7_{\mathrm{b}}$ \\
\hline Being anxious about the journey (e.g. delays or where to get off) & $13.7_{\mathrm{a}}$ & $15.0_{\mathrm{b}}$ & $15.0_{\mathrm{a}}$ & $14.0_{\mathrm{a}}$ & $15.8 \mathrm{a}$ & $12.8 \mathrm{a}$ & $12.6_{\mathrm{a}}$ & $13.3_{\mathrm{a}}$ & $13.0_{\mathrm{a}}$ & $9.8_{\mathrm{a}}$ & $14.8 \mathrm{a}$ & $14.4_{\mathrm{a}}$ & $14.1_{\mathrm{a}, \mathrm{b}}$ & $15.6_{b}$ & $12.9 \mathrm{a}$ \\
\hline Planning onward or return journey & $3.3_{\mathrm{a}}$ & $5.4_{\mathrm{b}}$ & $6.3_{\mathrm{a}}$ & $3.5_{\mathrm{b}}$ & $5.8_{\mathrm{a}}$ & $6.6_{\mathrm{a}}$ & $8.4_{b}$ & $11.9 \mathrm{a}$ & $6.1_{\mathrm{b}}$ & $6.8_{\mathrm{b}}$ & $6.3_{\mathrm{a}}$ & $7.3_{\mathrm{b}}$ & $12.3_{\mathrm{a}}$ & $6.7_{\mathrm{b}}$ & $4.0_{\mathrm{c}}$ \\
\hline Other & $0.0_{\mathrm{a}}$ & $0.0_{\mathrm{a}}$ & $0.0_{\mathrm{a}}$ & $0.0_{\mathrm{a}}$ & $0.0_{\mathrm{a}}$ & $0.0_{\mathrm{a}}$ & $0.0_{\mathrm{a}}$ & $0.0_{\mathrm{a}}$ & $0.0_{\mathrm{a}}$ & $0.0_{\mathrm{a}}$ & $0.0_{\mathrm{a}}$ & $0.0_{\mathrm{a}}$ & $0.0_{\mathrm{a}}$ & $0.0_{\mathrm{a}}$ & $0.0_{\mathrm{a}}$ \\
\hline Sample size & 5,646 & 6,675 & 4,026 & 7,992 & 400 & 2,323 & 1,744 & 663 & 3,090 & 337 & 3,899 & 6,692 & 2,021 & 5,523 & 3,211 \\
\hline
\end{tabular}

For each journey purpose and Gender/Age combination, each subscript letter denotes a subset of Wave categories whose column proportions do not differ significantly from each other at the .05 level 
Table 1d. Activities on which passengers spent most time while on the train based on journey duration (minutes) (2014 Autumn survey wave $\%$ of respondents per duration band across journey purposes)

\begin{tabular}{|c|c|c|c|c|c|c|c|c|c|c|c|c|}
\hline \multirow[b]{2}{*}{ Time use } & \multicolumn{4}{|c|}{ Commute } & \multicolumn{4}{|c|}{ Business } & \multicolumn{4}{|c|}{ Leisure } \\
\hline & $<30$ & $30-59$ & $60-119$ & $\geq 120$ & $<30$ & $30-59$ & $60-119$ & $\geq 120$ & $<30$ & $30-59$ & $60-119$ & $\geq 120$ \\
\hline Sleeping/snoozing & $1.8_{\mathrm{a}}$ & $4.4_{\mathrm{b}}$ & $8.3_{\mathrm{c}}$ & $5.4_{\mathrm{c}}$ & $1.8_{\mathrm{a}}$ & $2.6_{\mathrm{a}, \mathrm{b}}$ & $4.2_{\mathrm{b}}$ & $2.8_{\mathrm{a}, \mathrm{b}}$ & $0.9 \mathrm{a}$ & $1.7_{\mathrm{b}}$ & $5.0_{\mathrm{c}}$ & $4.0_{\mathrm{c}}$ \\
\hline Reading for leisure & $36.0_{\mathrm{a}}$ & $41.2_{\mathrm{b}}$ & $30.3_{\mathrm{c}}$ & $20.4_{d}$ & $22.0_{\mathrm{a}}$ & $23.7 \mathrm{a}$ & $22.9 \mathrm{a}$ & $20.6_{a}$ & $27.1_{\mathrm{a}}$ & $31.1_{\mathrm{b}}$ & $34.6_{c}$ & $42.5_{d}$ \\
\hline Working/studying (reading/writing/thinking) & $10.0_{\mathrm{a}}$ & $13.5_{\mathrm{b}}$ & $20.9 \mathrm{c}$ & $29.3_{\mathrm{d}}$ & $25.7 \mathrm{a}$ & $28.7_{a}$ & $35.8_{\mathrm{b}}$ & $38.7_{\mathrm{b}}$ & $4.4_{a}$ & $4.2_{\mathrm{a}}$ & $7.0_{\mathrm{b}}$ & $8.6_{b}$ \\
\hline Talking to other passengers & $3.9_{\mathrm{a}, \mathrm{b}}$ & $2.3_{\mathrm{c}}$ & $2.6_{c}$ & $6.1_{\mathrm{a}}$ & $5.3_{\mathrm{a}}$ & $5.0_{\mathrm{a}}$ & $3.9_{\mathrm{a}}$ & $5.7 \mathrm{a}$ & $12.6_{\mathrm{a}}$ & $13.4_{\mathrm{a}}$ & $7.8_{\mathrm{b}}$ & $7.5_{\mathrm{b}}$ \\
\hline Window gazing/people watching & $15.8_{\mathrm{a}}$ & $7.3_{\mathrm{b}}$ & $4.8_{\mathrm{c}}$ & $8.2_{\mathrm{b}, \mathrm{c}}$ & $15.3_{\mathrm{a}}$ & $16.5_{\mathrm{a}}$ & $6.3_{\mathrm{b}}$ & $5.7_{\mathrm{b}}$ & $33.9 \mathrm{a}$ & $27.3_{\mathrm{b}}$ & $26.0_{\mathrm{b}}$ & $18.8_{\mathrm{c}}$ \\
\hline Listening to music/radio/podcast & $9.9_{\mathrm{a}}$ & $8.8_{a}$ & $10.4_{\mathrm{a}}$ & $7.5_{\mathrm{a}}$ & $4.5_{\mathrm{a}, \mathrm{b}}$ & $3.5_{\mathrm{b}}$ & $4.6_{\mathrm{a}, \mathrm{b}}$ & $6.4_{\mathrm{a}}$ & $3.3_{\mathrm{a}}$ & $6.0_{\mathrm{b}}$ & $5.5_{\mathrm{b}}$ & $5.3_{\mathrm{b}}$ \\
\hline Watching a film/video & $0.8_{\mathrm{a}}$ & $2.4_{\mathrm{b}}$ & $5.3_{\mathrm{c}}$ & $6.8_{\mathrm{c}}$ & $0.9 \mathrm{a}$ & $0.4_{a}$ & $4.2_{\mathrm{b}}$ & $3.5 \mathrm{~b}$ & $0.2_{\mathrm{a}}$ & $0.6_{\mathrm{b}}$ & $0.9 \mathrm{~b}$ & $1.9 \mathrm{c}$ \\
\hline Text messages/phone calls - work & $1.2_{\mathrm{a}, \mathrm{b}}$ & $1.3_{\mathrm{b}}$ & $0.5_{\mathrm{a}}$ & $1.4_{\mathrm{a}, \mathrm{b}}$ & $4.1_{\mathrm{a}}$ & $3.9 \mathrm{a}$ & $3.3_{\mathrm{a}}$ & $2.5_{\mathrm{a}}$ & $0.4_{a}$ & $0.3_{\mathrm{a}}$ & $0.3_{\mathrm{a}}$ & $0.1_{\mathrm{a}}$ \\
\hline Text messages/phone calls - personal & $3.4_{\mathrm{a}}$ & $2.4_{\mathrm{b}}$ & $1.7_{\mathrm{b}}$ & $3.4_{\mathrm{a}, \mathrm{b}}$ & $2.3_{\mathrm{a}}$ & $1.1_{\mathrm{b}}$ & $1.1_{\mathrm{a}, \mathrm{b}}$ & $1.8_{\mathrm{a}, \mathrm{b}}$ & $3.9 \mathrm{a}$ & $3.1_{\mathrm{a}, \mathrm{b}}$ & $2.0_{\mathrm{b}}$ & $1.8_{\mathrm{b}}$ \\
\hline Checking emails & $4.0_{\mathrm{a}}$ & $4.7 \mathrm{a}$ & $5.4_{a}$ & $3.4_{a}$ & $6.2_{\mathrm{a}}$ & $8.3_{\mathrm{a}}$ & $8.8_{\mathrm{a}}$ & $7.1_{\mathrm{a}}$ & $1.0_{\mathrm{a}, \mathrm{b}}$ & $1.3_{\mathrm{b}, \mathrm{c}}$ & $1.7_{\mathrm{c}}$ & $0.3_{\mathrm{a}}$ \\
\hline Internet browsing & $3.9 \mathrm{a}$ & $3.9 \mathrm{a}$ & $2.0_{\mathrm{b}}$ & $2.0_{\mathrm{a}, \mathrm{b}}$ & $3.2 \mathrm{a}$ & $1.8_{\mathrm{a}}$ & $0.6_{\mathrm{b}}$ & $1.4_{\mathrm{a}, \mathrm{b}}$ & $1.8 \mathrm{a}$ & $2.0_{\mathrm{a}}$ & $1.9 \mathrm{a}$ & $1.7 \mathrm{a}$ \\
\hline Accessing social networking sites & $2.4_{a}$ & $1.1_{\mathrm{b}}$ & $0.7_{\mathrm{b}}$ & $1.4_{\mathrm{a}, \mathrm{b}}$ & $0.4_{a}$ & $1.2_{\mathrm{a}}$ & $0.3_{\mathrm{a}}$ & $0.7 \mathrm{a}$ & $2.2_{\mathrm{a}}$ & $0.9_{\mathrm{b}}$ & $0.7_{\mathrm{b}}$ & $0.7_{\mathrm{b}}$ \\
\hline Eating/drinking & $0.4_{\mathrm{a}}$ & $0.5_{\mathrm{a}}$ & $0.1_{\mathrm{a}}$ & $0.0_{\mathrm{a}}$ & $1.4_{\mathrm{a}}$ & $0.9 \mathrm{a}$ & $0.6_{\mathrm{a}}$ & $0.7 \mathrm{a}$ & $0.4_{\mathrm{a}}$ & $0.7 \mathrm{a}$ & $0.7 \mathrm{a}$ & $1.0_{\mathrm{a}}$ \\
\hline Caring for someone travelling with you (including children) & $0.5_{\mathrm{a}}$ & $0.8_{\mathrm{a}}$ & $0.2_{\mathrm{a}}$ & $0.0_{\mathrm{a}}$ & $0.1_{\mathrm{a}}$ & $0.0_{\mathrm{a}}$ & $0.0_{\mathrm{a}}$ & $0.0_{\mathrm{a}}$ & $3.4_{\mathrm{a}}$ & $2.5_{\mathrm{a}, \mathrm{b}}$ & $1.6_{\mathrm{b}}$ & $1.9_{\mathrm{b}}$ \\
\hline Playing games (electronic or otherwise) & $2.0_{\mathrm{a}}$ & $2.0_{\mathrm{a}}$ & $2.5 \mathrm{a}$ & $0.7 \mathrm{a}$ & $1.2 \mathrm{a}$ & $0.7 \mathrm{a}$ & $1.1_{\mathrm{a}}$ & $0.7 \mathrm{a}$ & $0.8_{\mathrm{a}}$ & $1.4_{\mathrm{b}}$ & $1.6_{\mathrm{b}}$ & $1.4_{\mathrm{a}, \mathrm{b}}$ \\
\hline Being bored & $2.5_{\mathrm{a}, \mathrm{b}}$ & $1.9_{\mathrm{b}}$ & $3.2_{\mathrm{a}}$ & $1.4_{\mathrm{a}, \mathrm{b}}$ & $2.2_{\mathrm{a}}$ & $0.5 \mathrm{~b}$ & $1.4_{\mathrm{a}}$ & $1.8_{\mathrm{a}}$ & $2.1_{\mathrm{a}}$ & $2.4_{a}$ & $1.8 \mathrm{a}$ & $1.2_{\mathrm{a}}$ \\
\hline Being anxious about the journey (e.g. delays or where to get off) & $1.1_{\mathrm{a}}$ & $1.2 \mathrm{a}$ & $0.6_{\mathrm{a}}$ & $2.0_{\mathrm{a}}$ & $1.5 \mathrm{a}$ & $0.3_{\mathrm{b}}$ & $0.2_{\mathrm{b}}$ & $0.0_{\mathrm{b}}$ & $0.6_{a}$ & $0.6_{a}$ & $0.6_{a}$ & $1.1_{\mathrm{a}}$ \\
\hline Planning onward or return journey & $0.5_{\mathrm{a}}$ & $0.4_{a}$ & $0.4_{a}$ & $0.7 \mathrm{a}$ & $1.7 \mathrm{a}$ & $1.1_{\mathrm{a}, \mathrm{b}}$ & $0.6_{\mathrm{a}, \mathrm{b}}$ & $0.0_{\mathrm{b}}$ & $1.1_{\mathrm{a}}$ & $0.5_{\mathrm{b}}$ & $0.3_{\mathrm{b}}$ & $0.3_{\mathrm{b}}$ \\
\hline Other & $0.0_{\mathrm{a}}$ & $0.0_{\mathrm{a}}$ & $0.0_{\mathrm{a}}$ & $0.0_{\mathrm{a}}$ & $0.1_{\mathrm{a}}$ & $0.0_{\mathrm{a}}$ & $0.0_{\mathrm{a}}$ & $0.0_{\mathrm{a}}$ & $0.1_{\mathrm{a}}$ & $0.1_{\mathrm{a}}$ & $0.0_{\mathrm{a}}$ & $0.0_{\mathrm{a}}$ \\
\hline Sample size & 4,390 & 3,098 & 809 & 147 & 777 & 1,006 & 637 & 282 & 3,142 & 2,229 & 1,149 & 723 \\
\hline
\end{tabular}

Each subscript letter denotes, per journey purpose, a subset of duration categories whose column proportions do not differ significantly from each other at the 0.05 level 
Table 2. Item used while on the train, and item to hand for 2014 wave (\% of respondents in each Autumn survey wave by journey purpose)

\begin{tabular}{|c|c|c|c|c|c|c|c|c|c|c|c|c|c|c|c|c|}
\hline \multirow[b]{2}{*}{ Item used } & \multicolumn{4}{|c|}{ All purposes } & \multicolumn{4}{|c|}{ Commute } & \multicolumn{4}{|c|}{ Business } & \multicolumn{4}{|c|}{ Leisure } \\
\hline & 2004 & 2010 & 2014 & $\begin{array}{r}2014 \\
\text { to hand }\end{array}$ & 2004 & 2010 & 2014 & $\begin{array}{c}2014 \\
\text { to hand }\end{array}$ & 2004 & 2010 & 2014 & $\begin{array}{c}2014 \\
\text { to hand }\end{array}$ & 2004 & 2010 & 2014 & $\begin{array}{r}2014 \\
\text { to hand }\end{array}$ \\
\hline Newspaper & $28.3_{\mathrm{a}}$ & $29.5_{b}$ & $21.6_{c}$ & 35.8 & $30.3_{\mathrm{a}}$ & $35.3_{\mathrm{b}}$ & $24.4_{c}$ & 40.2 & $31.8_{\mathrm{a}}$ & $28.5_{b}$ & $21.2_{\mathrm{c}}$ & 34.1 & $24.7 \mathrm{a}$ & $22.8_{\mathrm{b}}$ & $18.5_{\mathrm{c}}$ & 31.3 \\
\hline Reading book & $19.6_{a}$ & $18.8_{\mathrm{a}}$ & $11.7_{\mathrm{b}}$ & 25.8 & $23.5_{\mathrm{a}}$ & $21.6_{\mathrm{b}}$ & $12.2_{\mathrm{c}}$ & 27.0 & $14.5_{\mathrm{a}}$ & $15.1_{\mathrm{a}}$ & $9.3_{\mathrm{b}}$ & 22.2 & $17.2_{\mathrm{a}}$ & $17.0_{\mathrm{a}}$ & $12.2_{\mathrm{b}}$ & 25.7 \\
\hline Text book & $3.1_{\mathrm{a}}$ & $2.6_{b}$ & $1.6_{\mathrm{c}}$ & 4.8 & $3.9 \mathrm{a}$ & $3.3_{\mathrm{a}}$ & $1.8_{\mathrm{b}}$ & 5.9 & $3.6_{\mathrm{a}}$ & $2.9 \mathrm{a}$ & $1.6_{\mathrm{b}}$ & 5.8 & $2.1_{\mathrm{a}}$ & $1.5_{\mathrm{b}}$ & $1.5_{\mathrm{b}}$ & 3.2 \\
\hline Magazine & $7.7 \mathrm{a}$ & $6.0_{\mathrm{b}}$ & $3.9_{\mathrm{c}}$ & 9.0 & $5.3_{\mathrm{a}}$ & $4.2_{\mathrm{b}}$ & $3.0_{\mathrm{c}}$ & 7.6 & $8.4_{\mathrm{a}}$ & $5.4_{b}$ & $4.2_{\mathrm{c}}$ & 8.4 & $10.2_{\mathrm{a}}$ & $8.4_{b}$ & $5.0_{\mathrm{c}}$ & 10.7 \\
\hline Paperwork & $11.8_{\mathrm{a}}$ & $9.9_{b}$ & $6.5_{\mathrm{c}}$ & 15.4 & $9.9 \mathrm{a}$ & $8.9_{b}$ & $5.8_{\mathrm{c}}$ & 16.2 & $32.2_{\mathrm{a}}$ & $25.2_{\mathrm{b}}$ & $17.7_{\mathrm{c}}$ & 34.4 & $5.8_{\mathrm{a}}$ & $5.0_{\mathrm{b}}$ & $3.2_{\mathrm{c}}$ & 7.1 \\
\hline Games/puzzles & $1.3_{\mathrm{a}}$ & $2.2_{\mathrm{b}}$ & $2.3_{\mathrm{b}}$ & 5.8 & $0.6_{a}$ & $1.9_{\mathrm{b}}$ & $2.0_{\mathrm{b}}$ & 5.6 & $1.0_{\mathrm{a}}$ & $1.7_{\mathrm{b}}$ & $2.6_{c}$ & 6.1 & $2.2_{\mathrm{a}}$ & $2.7_{\mathrm{b}}$ & $2.7_{\mathrm{a}, \mathrm{b}}$ & 5.9 \\
\hline Food/drink & $18.1_{\mathrm{a}}$ & $15.1_{b}$ & $10.4_{c}$ & 20.0 & $10.3_{\mathrm{a}}$ & $10.5_{\mathrm{a}}$ & $6.9_{\mathrm{b}}$ & 16.4 & $25.7_{\mathrm{a}}$ & $19.3_{\mathrm{b}}$ & $15.0_{\mathrm{c}}$ & 24.4 & $23.6_{a}$ & $19.1_{b}$ & $12.8_{\mathrm{c}}$ & 22.5 \\
\hline Laptop computer & $2.0_{\mathrm{a}}$ & $3.2_{\mathrm{b}}$ & $3.8_{\mathrm{c}}$ & 13.3 & $1.8_{\mathrm{a}}$ & $3.0_{\mathrm{b}}$ & $3.4_{b}$ & 13.7 & $6.9 \mathrm{a}$ & $9.5_{b}$ & $11.1_{\mathrm{c}}$ & 32.5 & $0.3_{\mathrm{a}}$ & $1.0_{\mathrm{b}}$ & $1.5_{\mathrm{c}}$ & 5.6 \\
\hline Mobile phones (calls and texts) & $23.9 \mathrm{a}$ & $35.2_{\mathrm{b}}$ & $26.9_{\mathrm{c}}$ & 58.1 & $22.1_{\mathrm{a}}$ & $37.0_{\mathrm{b}}$ & $28.2_{\mathrm{c}}$ & 60.2 & $34.2_{\mathrm{a}}$ & $44.9_{\mathrm{b}}$ & $33.9 \mathrm{a}$ & 66.7 & $21.6_{a}$ & $29.2_{b}$ & $22.7 \mathrm{a}$ & 52.6 \\
\hline Smartphone & $\mathrm{N} / \mathrm{A}$ & N/A & 26.5 & 43.3 & $\mathrm{~N} / \mathrm{A}$ & N/A & 30.6 & 50.5 & N/A & N/A & 33.9 & 53.0 & N/A & $\mathrm{N} / \mathrm{A}$ & 18.9 & 31.3 \\
\hline Portable DVD player & N/A & $0.3_{\mathrm{a}}$ & $0.2_{\mathrm{b}}$ & 0.4 & $\mathrm{~N} / \mathrm{A}$ & $0.4_{a}$ & $0.2_{\mathrm{b}}$ & 0.5 & N/A & $0.2_{\mathrm{a}}$ & $0.1_{\mathrm{a}}$ & 0.2 & N/A & $0.2 \mathrm{a}$ & $0.2_{\mathrm{a}}$ & 0.5 \\
\hline MP3 player/music player (eg iPod) & $6.3_{\mathrm{a}}$ & $11.7_{\mathrm{b}}$ & $5.6_{c}$ & 11.6 & $8.4_{a}$ & $15.3_{\mathrm{b}}$ & $7.5_{\mathrm{c}}$ & 14.7 & $3.4_{a}$ & $8.7_{b}$ & $4.4_{\mathrm{a}}$ & 10.4 & $5.0_{\mathrm{a}}$ & $8.6_{b}$ & $4.0_{\mathrm{c}}$ & 8.4 \\
\hline Games console & $0.2_{\mathrm{a}}$ & $0.4_{\mathrm{b}}$ & $0.2_{\mathrm{a}}$ & 0.5 & $0.2_{\mathrm{a}}$ & $0.5 \mathrm{~b}$ & $0.2_{\mathrm{a}}$ & 0.6 & $0.1_{\mathrm{a}}$ & $0.2 \mathrm{a}$ & $0.2_{\mathrm{a}}$ & 0.4 & $0.2_{\mathrm{a}}$ & $0.5 \mathrm{~b}$ & $0.2 \mathrm{a}$ & 0.5 \\
\hline eBook reader/tablet computer & $\mathrm{N} / \mathrm{A}$ & $1.2 \mathrm{a}$ & $8.1_{b}$ & 16.7 & $\mathrm{~N} / \mathrm{A}$ & $1.5_{\mathrm{a}}$ & $9.7_{b}$ & 18.8 & N/A & $1.6_{a}$ & $9.5_{b}$ & 20.1 & N/A & $0.7 \mathrm{a}$ & $5.6_{\mathrm{b}}$ & 12.9 \\
\hline PDA/handheld computer & 2.1 & N/A & N/A & $N / A$ & 2.2 & N/A & N/A & $N / A$ & 5.4 & N/A & N/A & $N / A$ & 0.7 & N/A & N/A & $N / A$ \\
\hline Netbook & N/A & $0.5 \%$ & N/A & $N / A$ & N/A & 0.5 & N/A & $N / A$ & N/A & 1.2 & N/A & $N / A$ & N/A & 0.3 & N/A & $N / A$ \\
\hline Not stated/no answer & $31.5_{\mathrm{a}}$ & $28.4_{b}$ & $34.7_{\mathrm{c}}$ & 6.1 & $28.4_{a}$ & $23.1_{b}$ & $30.4_{c}$ & 3.4 & $23.3_{\mathrm{a}}$ & $22.5_{\mathrm{a}}$ & $28.4_{b}$ & 4.0 & $38.3_{\mathrm{a}}$ & $37.1_{\mathrm{a}}$ & $42.2_{b}$ & 10.0 \\
\hline Sample size & 25,596 & 27,556 & 27,812 & 27,812 & 11,327 & 12,728 & 12,644 & 12,644 & 4,055 & 4,243 & 4,191 & 4,191 & 10,215 & 10,584 & 10,978 & 10,978 \\
\hline
\end{tabular}

Each subscript letter denotes, per journey purpose, a subset of survey wave categories whose column proportions to do differ significantly from each other at the 0.05 level 
Table 3. 'Thinking about the time you spent on the train, which one of the following statements do you most agree with?' (\% of respondents)

\begin{tabular}{|c|c|c|c|c|c|}
\hline Journey purpose & Wave & $\begin{array}{l}\text { I made very } \\
\text { worthwhile } \\
\text { use of my } \\
\text { time on this } \\
\text { train today }\end{array}$ & $\begin{array}{r}\text { I made } \\
\text { some use of } \\
\text { my time on } \\
\text { this train } \\
\text { today }\end{array}$ & $\begin{array}{r}\text { My time } \\
\text { spent on } \\
\text { this train is } \\
\text { wasted time }\end{array}$ & $\begin{array}{r}\text { Sample } \\
\text { size }\end{array}$ \\
\hline \multirow[t]{4}{*}{ Commute } & 2004 & $22.9_{\mathrm{a}}$ & $54.5_{\mathrm{a}}$ & $22.7_{\mathrm{a}}$ & 11,042 \\
\hline & 2010 & $27.9_{b}$ & $55.9_{\mathrm{a}}$ & $16.2_{\mathrm{b}}^{\mathrm{c}}$ & 12,359 \\
\hline & 2014 & $26.8_{\mathrm{b}}$ & $57.7_{\mathrm{b}}$ & $15.5_{\mathrm{b}}$ & 12,302 \\
\hline & All & 26.0 & 56.1 & 18.0 & 35,703 \\
\hline \multirow[t]{4}{*}{ Business } & 2004 & $28.0_{\mathrm{a}}$ & $59.0_{a}$ & $13.0_{\mathrm{a}}$ & 3,956 \\
\hline & 2010 & $34.3_{\mathrm{b}}$ & $57.4_{a}$ & $8.4_{\mathrm{b}}$ & 4,127 \\
\hline & 2014 & $34.8_{\mathrm{b}}$ & $56.5_{\mathrm{a}}$ & $8.8_{\mathrm{b}}$ & 4,067 \\
\hline & All & 32.4 & 57.6 & 10.0 & 12,150 \\
\hline \multirow[t]{4}{*}{ Leisure } & 2004 & $24.8_{\mathrm{a}}$ & $57.7_{\mathrm{a}}$ & $17.5_{\mathrm{a}}$ & 9,638 \\
\hline & 2010 & $32.6_{b}$ & $55.2_{\mathrm{b}}$ & $12.2 \mathrm{~b}$ & 10,013 \\
\hline & 2014 & $33.4_{\mathrm{b}}$ & $56.4_{a, b}$ & $10.2_{\mathrm{c}}$ & 10,453 \\
\hline & All & 30.3 & 56.4 & 13.2 & 30,104 \\
\hline \multirow[t]{4}{*}{ All } & 2004 & $24.4_{a}$ & $56.5_{\mathrm{a}, \mathrm{b}}$ & $\overline{19.1_{\mathrm{a}}}$ & 24,636 \\
\hline & 2010 & $30.7_{b}$ & $55.9_{\mathrm{b}}$ & $13.5_{\mathrm{b}}$ & 26,501 \\
\hline & 2014 & $30.6_{b}$ & $57.0_{\mathrm{a}}$ & $12.4_{\mathrm{c}}$ & 26,821 \\
\hline & All & 28.7 & 56.5 & 14.9 & 77,958 \\
\hline Gender & Male & $30.3_{a}$ & $56.5_{a}$ & $13.2_{a}$ & 11,574 \\
\hline (2014) & Female & $30.7_{a}$ & $57.4_{a}$ & $11.8_{b}$ & 14,666 \\
\hline Age & $\leq 34$ & $21.3_{a}$ & $59.5_{a}$ & $19.2_{a}$ & 6,589 \\
\hline \multirow[t]{2}{*}{ (2014) } & $35-64$ & $32.6_{b}$ & $56.9_{b}$ & $10.6_{b}$ & 16,162 \\
\hline & $\geq 65$ & $38.1_{c}$ & $53.4_{c}$ & $8.4_{c}$ & 3,724 \\
\hline Time of Journey & Peak & $26.4_{a}$ & $59.6_{a}$ & $14.0_{a}$ & 11,574 \\
\hline$(2014)$ & Off peak & $31.4_{b}$ & $56.7_{b}$ & $11.9_{b}$ & 14,666 \\
\hline
\end{tabular}

For each category in the first column, each subscript letter denotes a subset of whose row proportions do not differ significantly from each other at the .05 level 
Table 4. Proxy measures of passenger experience (\% of respondents in each Autumn survey wave)

\begin{tabular}{lllllll}
\hline $\begin{array}{l}\text { How would you rate the train you boarded for that journey in terms of } \\
\text { sufficient room for all the passengers to sit/stand? }\end{array}$ \\
\begin{tabular}{rlrllll} 
Wave & $\begin{array}{l}\text { Very } \\
\text { good }\end{array}$ & $\begin{array}{l}\text { Fairly } \\
\text { good }\end{array}$ & $\begin{array}{l}\text { Neither } \\
\text { good nor } \\
\text { poor }\end{array}$ & Fairly poor & Very poor & $\begin{array}{l}\text { Sample } \\
\text { size }\end{array}$ \\
\hline 2004 & 20.6 & 38.5 & 16.9 & 11.8 & 12.1 & 23,939 \\
2010 & 27.1 & 41.0 & 14.1 & 9.9 & 7.9 & 26,179 \\
2014 & 25.1 & 39.1 & 14.3 & 10.5 & 11.1 & 26,228 \\
\hline
\end{tabular}
\end{tabular}

Taking account of the station where you boarded the train and the actual train travelled on how satisfied were you with your journey today?

\begin{tabular}{lllllll}
\hline Wave & $\begin{array}{l}\text { Very } \\
\text { satisfied }\end{array}$ & $\begin{array}{l}\text { Fairly } \\
\text { satisfied }\end{array}$ & $\begin{array}{l}\text { Neither } \\
\text { satisfied } \\
\text { nor } \\
\text { dissatisfied }\end{array}$ & $\begin{array}{l}\text { Fairly } \\
\text { dissatisfied }\end{array}$ & $\begin{array}{l}\text { Very } \\
\text { dissatisfied }\end{array}$ & $\begin{array}{l}\text { Sample } \\
\text { size }\end{array}$ \\
\hline 2004 & 27.8 & 48.1 & 14.5 & 6.9 & 2.8 & 24,954 \\
2010 & 36.1 & 47.5 & 10.3 & 4.1 & 2.0 & 26,881 \\
2014 & 32.5 & 48.7 & 11.6 & 5.3 & 2.0 & 27,053 \\
\hline
\end{tabular}


Table 5. 'Which one of the following statements do you most agree with concerning today's journey? How I could use my time today when travelling was...' (\% of respondents for 2014)

\begin{tabular}{|c|c|c|c|c|c|}
\hline & & $\begin{array}{l}\text { The main } \\
\text { reason for } \\
\text { choosing } \\
\text { to travel } \\
\text { by train }\end{array}$ & $\begin{array}{r}\text { One of the } \\
\text { important } \\
\text { factors in } \\
\text { choosing to } \\
\text { travel by } \\
\text { train }\end{array}$ & $\begin{array}{r}\text { Not an } \\
\text { important } \\
\text { factor in } \\
\text { choosing to } \\
\text { travel by train }\end{array}$ & $\begin{array}{r}\text { Sample } \\
\text { Size }\end{array}$ \\
\hline \multirow{3}{*}{ Journey purpose } & Commuting & 10.8 & 13.8 & 75.5 & 12,211 \\
\hline & Business & 12.3 & 22.6 & 65.1 & 4,072 \\
\hline & Leisure & 14.6 & 13.2 & 72.2 & 10,502 \\
\hline \multirow{4}{*}{$\begin{array}{l}\text { Time spent on train } \\
\text { (minutes) }\end{array}$} & $<30$ & 12.5 & 12.3 & 75.2 & 11,850 \\
\hline & $30-59$ & 12.3 & 15.4 & 72.2 & 8,912 \\
\hline & $60-119$ & 11.9 & 17.8 & 70.3 & 3,609 \\
\hline & $\geq 120$ & 14.2 & 22.9 & 63.0 & 1,572 \\
\hline \multirow{3}{*}{ Age (years) } & $\leq 34$ & 10.5 & 13.0 & 76.5 & 6,554 \\
\hline & $35-64$ & 12.0 & 15.8 & 72.2 & 16,170 \\
\hline & $\geq 65$ & 17.9 & 14.0 & 68.0 & 3,771 \\
\hline \multirow{2}{*}{ Gender } & Male & 13.3 & 17.0 & 69.7 & 11,597 \\
\hline & Female & 11.8 & 13.0 & 75.2 & 14,637 \\
\hline \multirow{2}{*}{$\begin{array}{l}\text { Journey destination } \\
\text { station }\end{array}$} & London & 11.6 & 13.5 & 75.0 & 11,939 \\
\hline & Non-London & 13.3 & 16.0 & 70.7 & 14,844 \\
\hline Total sample & Total & 12.5 & 14.9 & 72.6 & 26,785 \\
\hline
\end{tabular}


Table 6. 'To what extent had you planned in advance how you would spend the time on this train?"' (\% of respondents for each survey wave)

\begin{tabular}{llrrrrr}
\hline $\begin{array}{l}\text { Survey } \\
\text { wave }\end{array}$ & $\begin{array}{l}\text { Journey } \\
\text { Purpose }\end{array}$ & A lot & A little & $\begin{array}{r}\text { Very little as I } \\
\text { always use my } \\
\text { journey time the } \\
\text { same way }\end{array}$ & $\begin{array}{r}\text { Not at } \\
\text { all }\end{array}$ & $\begin{array}{r}\text { Sample } \\
\text { Size }\end{array}$ \\
\hline \multirow{3}{*}{2004} & Commuting & 11.8 & 39.3 & N/A & 48.9 & 10,288 \\
& Business & 20.6 & 47.5 & N/A & 31.9 & 3.817 \\
& Leisure & 9.1 & 39.5 & N/A & 51.3 & 8,232 \\
& Total & 12.3 & 40.8 & N/A & 46.9 & 22,337 \\
\hline \multirow{2}{*}{2010} & Commuting & 8.0 & 20.3 & 47.3 & 24.5 & 12,475 \\
& Business & 13.1 & 36.1 & 23.1 & 27.7 & 4,156 \\
& Leisure & 6.5 & 25.3 & 27.4 & 40.8 & 10,296 \\
& Total & 8.2 & 24.7 & 35.9 & 31.2 & 26,927 \\
\hline \multirow{2}{*}{2014} & Commuting & 10.0 & 20.4 & 46.3 & 23.3 & 12,399 \\
& Business & 15.3 & 38.5 & 22.0 & 24.2 & 4,111 \\
& Leisure & 8.4 & 26.5 & 24.8 & 40.3 & 10,705 \\
& Total & 10.2 & 25.5 & 34.2 & 30.1 & 27,215 \\
\hline
\end{tabular}


Table 7. 'To what extent did any electronic devices you had with you today make the time you spent on this train better? (\% of respondents)

\begin{tabular}{|c|c|c|c|c|c|c|c|c|c|c|c|}
\hline & & \multicolumn{5}{|c|}{2004} & \multicolumn{5}{|c|}{2014} \\
\hline & & A lot & A little & Not at all & N/A & $\begin{array}{c}\text { Sample } \\
\text { size }\end{array}$ & A lot & A little & Not at all & N/A & $\begin{array}{c}\text { Sample } \\
\text { size }\end{array}$ \\
\hline \multirow{3}{*}{$\begin{array}{l}\text { Journey } \\
\text { purpose }\end{array}$} & Commuting & 14.3 & 19.4 & 28.6 & 37.7 & 10,967 & 37.4 & 30.8 & 15.4 & 16.4 & 12,345 \\
\hline & Business & 18.4 & 22.5 & 28.7 & 30.4 & 3,925 & 38.6 & 34.3 & 14.9 & 12.3 & 4,092 \\
\hline & Leisure & 8.8 & 17.1 & 25.1 & 48.9 & 9,563 & 19.0 & 27.0 & 22.4 & 31.5 & 10,611 \\
\hline \multirow{4}{*}{$\begin{array}{l}\text { Time spent on } \\
\text { train (minutes) }\end{array}$} & $<30$ & 10.8 & 16.0 & 27.4 & 45.8 & 10,443 & 25.3 & 28.9 & 19.8 & 25.9 & 11,976 \\
\hline & $30-59$ & 12.8 & 19.7 & 29.1 & 38.4 & 7,974 & 33.8 & 30.8 & 17.0 & 18.4 & 8,997 \\
\hline & $60-119$ & 15.7 & 22.7 & 24.8 & 36.9 & 4,127 & 36.9 & 30.2 & 16.4 & 16.5 & 3,643 \\
\hline & $\geq 120$ & 18.4 & 26.3 & 22.6 & 32.7 & 1,630 & 39.4 & 30.2 & 13.7 & 16.7 & 1,587 \\
\hline \multirow{3}{*}{ Age (years) } & $\leq 34$ & 19.6 & 27.3 & 24.5 & 28.7 & 8,407 & 43.8 & 35.4 & 10.7 & 10.1 & 6,631 \\
\hline & $35-64$ & 10.3 & 15.9 & 29.8 & 44.1 & 14,021 & 29.8 & 30.7 & 19.2 & 20.3 & 16,318 \\
\hline & $\geq 65$ & 2.0 & 5.6 & 21.3 & 71.1 & 1,916 & 9.0 & 17.1 & 26.3 & 47.6 & 3,801 \\
\hline \multirow{2}{*}{ Gender } & Male & 14.2 & 18.3 & 27.5 & 40.0 & 11,358 & 31.0 & 30.3 & 18.0 & 20.7 & 11,685 \\
\hline & Female & 11.6 & 19.6 & 27.0 & 41.7 & 12,985 & 30.0 & 29.6 & 18.1 & 22.4 & 14,807 \\
\hline
\end{tabular}

